\title{
A New Sparteine Surrogate for Asymmetric Deprotonation of $N$-Boc Pyrrolidine
}

\author{
Darren Stead, Peter O'Brien* and Adam J. Sanderson
}

Department of Chemistry, University of York, Heslington, York YO10 5DD, U.K.

Eli Lilly and Co. Ltd, Lilly Research Centre, Erl Wood Manor, Sunninghill Rd,

Windlesham, Surrey, GU20 6PH, U.K.

paob1@york.ac.uk

Supporting Information Available: Full experimental procedures and characterisation data.

\section{Table of contents:}

\section{S2 General}

S3 Full experimental procedures and characterisation data

S24 Representative GC/HPLC data

S32 References for supporting information 


\section{General}

Water is distilled water. Where necessary, solvents were dried on a MBraun SPS solvent purification system or distilled before use. $\mathrm{Et}_{2} \mathrm{O}$ and $\mathrm{THF}$ were freshly distilled from sodium and benzophenone. $s$ BuLi was titrated against $N$-benzylbenzamide or by acid/base double titration before use. Petrol refers to the fraction of petroleum ether with a boiling point range of $40-60{ }^{\circ} \mathrm{C}$. Diamines used in lithiation reactions were distilled from $\mathrm{CaH}_{2}$ before use. All reactions were carried out under oxygen-free nitrogen or argon using oven-dried and/or flame dried glassware. Flash column chromatography was carried out using Fluka Silica gel 60 (0.035-0.070 mm particle size). Thin layer chromatography was carried using Merck $\mathrm{F}_{254}$ aluminium-backed silica plates. For Kügelrohr distillations, the oven temperatures are quoted.

Proton (270 MHz or $400 \mathrm{MHz}$ ) and carbon (100.6 MHz) NMR spectra were recorded on a Jeol EX 270 or a Joel ECX-400 instrument using an internal deuterium lock. All samples were recorded in $\mathrm{CDCl}_{3}$. Chemical shifts are quoted in parts per million and referenced to $\mathrm{CHCl}_{3}\left(7.27\right.$ for ${ }^{1} \mathrm{H} \mathrm{NMR}$ and 77.0 for ${ }^{13} \mathrm{C}$ NMR spectroscopy). Carbon NMR spectra were recorded with broadband proton decoupling and were assigned using DEPT and HSQC experiments. Infra-red spectra were recorded on an ATI Matteson Genesis FT-IR spectrometer. Chemical ionisation and high resolution mass spectra were recorded on a Fisons Analytical (VG) Autospec spectrometer. Electrospray ionisation low and high resolution mass spectra were recorded on a Bruker Daltronics micrOTOF spectrometer.

Optical rotations were recorded at rt on a Jasco DIP-370 polarimeter (using the sodium D line; $259 \mathrm{~nm}$ ) and $[\alpha]_{\mathrm{D}}$ given in units of $10^{-1} \mathrm{deg} \mathrm{cm}^{3} \mathrm{~g}^{-1}$. Chiral stationary phase HPLC was performed on one of three systems: a Gilson system with 712 controller software and a $118 \mathrm{UV} / \mathrm{V}$ is diode array detector or on a Waters system with a Waters 255 pump and a Waters 2487 UV detector or an Agilent 1200 series chromatograph using the column indicated for individual compounds. Chiral stationary phase GC was performed on either an Agilent 6890 gas chromatograph using the column indicated for individual compounds or a Perkin Elmer Autosystem XL gas chromatograph. Melting points were measured on a Gallenkamp melting point apparatus. 


\section{Full experimental procedures and characterisation data}

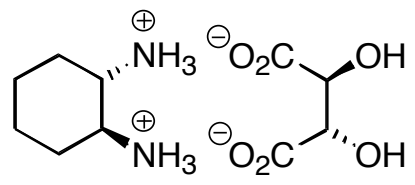

$(S, S)-5$

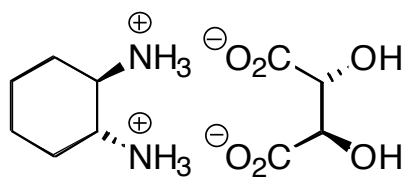

$(R, R)-5$

\section{$(1 S, 2 S)$-Cyclohexane-1,2-diamine 2,3-dihydroxysuccinate salt $\quad(S, S)-5$ and $(1 R, 2 R)$ -}

\section{Cyclohexane-1,2-diamine 2,3-dihydroxysuccinate salt $(R, R)-5$}

Trans ( \pm )-1,2 cyclohexane diamine $(20.00 \mathrm{~mL}, 100.00 \mathrm{mmol})$ was added dropwise to a stirred solution of D-tartaric acid $(12.51 \mathrm{~g}, 50.00 \mathrm{mmol})$ in water $(45 \mathrm{~mL})$ under air, such that the internal temperature did not exceed $70{ }^{\circ} \mathrm{C}$ (during this time a white precipitate forms, but this disappears by the point of complete addition). Then, $\mathrm{AcOH}(5 \mathrm{~mL})$ was added dropwise such that the internal temperature did not exceed 90 ${ }^{\circ} \mathrm{C}$. The resulting solution was allowed to cool to $5^{\circ} \mathrm{C}$ over $4 \mathrm{~h}$ and kept at $5{ }^{\circ} \mathrm{C}$ for $2 \mathrm{~h}$ (refrigerator). The solids were removed by filtration and the filter-cake was washed with cold water $\left(\leq 5{ }^{\circ} \mathrm{C}, 20 \mathrm{~mL}\right)$ and $\mathrm{MeOH}(5 \times 10 \mathrm{~mL})$ (Washings kept separate). The resulting white solid was sucked dry to give the $(1 S, 2 S)$ cyclohexane diamine D-tartaric acid salt $(S, S)-5\left(22.75 \mathrm{~g}, \geq 95 \%, \geq 99: 1\right.$ er by chiral shift ${ }^{1} \mathrm{H}$ NMR spectroscopy of the TMCDA derivative); mp 283-284 ${ }^{\circ} \mathrm{C}$ (lit., ${ }^{1} 280-284{ }^{\circ} \mathrm{C}$ ). The aqueous filtrate was combined with the aqueous washings and cooled to $0{ }^{\circ} \mathrm{C}$. L-tartaric acid $(12.51 \mathrm{~g}, 50.00 \mathrm{mmol})$ was then added portionwise to the solution over $5 \mathrm{~min}$. The resulting solution was stirred at $0{ }^{\circ} \mathrm{C}$ for $4 \mathrm{~h}$. The solids were removed by filtration and the filter-cake was washed with cold water $\left(\leq 5^{\circ} \mathrm{C}, 20 \mathrm{~mL}\right)$ and $\mathrm{MeOH}(5 \mathrm{x}$ $10 \mathrm{~mL})$. The resulting white solid was sucked dry to give the $(1 R, 2 R)$ cyclohexane diamine L-tartaric acid salt $(R, R)-5$ (19.05 g, 90\%, $\geq 99: 1$ er by chiral shift ${ }^{1} \mathrm{H}$ NMR spectroscopy of the TMCDA derivative); 275-276 ${ }^{\circ} \mathrm{C}$ (lit., ${ }^{1} 273{ }^{\circ} \mathrm{C}$ ); ${ }^{1} \mathrm{H}$ NMR (400 MHz, $\mathrm{CDCl}_{3}$ ) $\delta 4.16$ (s, 2H, C(O) $\left.{ }_{2} \mathrm{CHOH}\right), 3.22-3.12$ (m, $2 \mathrm{H}, 2$ x $\left.\mathrm{CHNH}_{3}^{+}\right), 2.04-1.92\left(\mathrm{~m}, 2 \mathrm{H}, 2 \times \mathrm{CH}_{\mathrm{A}} \mathrm{H}_{\mathrm{B}} \mathrm{CHN}\right), 1.72-1.60\left(\mathrm{~m}, 2 \mathrm{H}, 2 \times \mathrm{CH}_{\mathrm{A}} H_{\mathrm{B}} \mathrm{CHN}\right), 1.41-1.27(\mathrm{~m}, 2 \mathrm{H}$, $\left.2 \times \mathrm{CH}_{\mathrm{A}} \mathrm{H}_{\mathrm{B}} \mathrm{CH}_{2}\right)$, 1.25-1.11 (m, 2H, $2 \times \mathrm{CH}_{\mathrm{A}} \mathrm{H}_{\mathrm{B}} \mathrm{CH}_{2}$ ). Spectroscopic data consistent with that reported in the literature. ${ }^{1}$

The er of each salt was determined by conversion to TMCDA and ${ }^{1} \mathrm{H}$ NMR spectroscopy in the presence of 2,2,2 trifluoro-1-(9-anthryl)-ethanol using the following procedure: TMCDA (1 mg) was dissolved in $\mathrm{CDCl}_{3}(0.2 \mathrm{~mL})$ in a NMR sample tube, and to this a solution of $(R)-(-)$-2,2,2-trifluoro-1-(9- 
anthryl)-ethanol $(2.8 \mathrm{mg})$ in $\mathrm{CDCl}_{3}(0.3 \mathrm{~mL})$ was added. ${ }^{1} \mathrm{H}$ NMR spectroscopy then gave the er of TMCDA and hence tartaric acid salt 5.

\section{$(1 R, 2 R)-N^{1}, N^{2}$-Dimethylcyclohexane-1,2-diamine $(R, R)-6$}

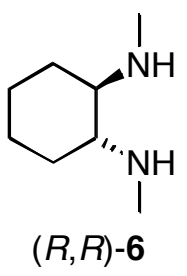

A solution of $\mathrm{NaOH}(12.24 \mathrm{~g}, 306.0 \mathrm{mmol})$ in water $(20 \mathrm{~mL})$ and methylchloroformate $(6.20 \mathrm{~mL}, 80.34$ mmol) were simultaneously added to a stirred suspension of L-tartaric acid salt $(R, R)-5(10.01 \mathrm{~g}, 37.9$ $\mathrm{mmol})$ in toluene $(50 \mathrm{~mL})$ at $0{ }^{\circ} \mathrm{C}$ under air. This led to the formation of a gel-like precipitate. The resulting mixture was stirred at $\mathrm{rt}$ for $48 \mathrm{~h}$. Then, $\mathrm{CHCl}_{3}(50 \mathrm{~mL})$ was added and the solids were removed by filtration and washed with $\mathrm{CHCl}_{3}(2 \times 25 \mathrm{~mL})$. Water $(25 \mathrm{~mL})$ was added to the filtrate and the two layers were separated. The aqueous layer was extracted with $\mathrm{CHCl}_{3}(2 \times 50 \mathrm{~mL})$. The combined organics were dried $\left(\mathrm{K}_{2} \mathrm{CO}_{3}\right)$ and evaporated under reduced pressure to give the crude carbamate $(8.69 \mathrm{~g}, \geq 99 \%$ crude yield, $\geq 95 \%$ purity by ${ }^{1} \mathrm{H}$ NMR spectroscopy) as a white solid, ${ }^{1} \mathrm{H}$ NMR (400 MHz, $\mathrm{CDCl}_{3}$ ) $\delta 3.63$ (s, $6 \mathrm{H}, 2$ x OMe), 3.40-3.36 (m, 2H, 2 x NHCH), 2.09-1.98 (m, $\left.2 \mathrm{H}, \mathrm{NHCHCH}_{2}\right), 1.78-1.66$ (m, 2H, $\mathrm{NHCHCH}_{2}$ ), 1.35-1.11 (m, 4H, $\mathrm{CH}_{2} \mathrm{CH}_{2}$ ). A solution of the crude carbamate (max. $\left.37.9 \mathrm{mmol}\right)$ in THF $(60 \mathrm{~mL})$ was added dropwise via a dropping funnel to a stirred suspension of $\mathrm{LiAlH}_{4}(7.20 \mathrm{~g}, 189.6 \mathrm{mmol})$ in THF $(60 \mathrm{~mL})$ at $0{ }^{\circ} \mathrm{C}$ under $\mathrm{N}_{2}$. The resulting solution was stirred and heated at reflux for $40 \mathrm{~h}$. Then, the solution was cooled to $0{ }^{\circ} \mathrm{C}$ and $\mathrm{Et}_{2} \mathrm{O}(50 \mathrm{~mL})$ was added, followed by the portionwise addition of $\mathrm{Na}_{2} \mathrm{SO}_{4} \cdot 10 \mathrm{H}_{2} \mathrm{O}(36.0 \mathrm{~g})$. The resulting mixture was then stirred at $\mathrm{rt}$ for $1 \mathrm{~h}$. The solids were removed by filtration through a pad of Celite ${ }^{\circledR}$ and were washed with $24: 1 \mathrm{CH}_{2} \mathrm{Cl}_{2}-\mathrm{MeOH}(2 \times 50 \mathrm{~mL})$. The combined organics were dried $\left(\mathrm{K}_{2} \mathrm{CO}_{3}\right)$ and evaporated under reduced pressure to give crude diamine $(R, R)-6(5.39 \mathrm{~g}$, $\geq 99 \%$ crude yield) as a yellow oil, ${ }^{1} \mathrm{H}$ NMR (400 MHz, $\left.\mathrm{CDCl}_{3}\right) \delta 2.37$ (s, 6H, 2 x NMe), 2.12-2.04 (m, $2 \mathrm{H}, 2$ x NCH), 2.02-1.97 (m, 2H, $\left.\mathrm{NCHCH}_{2}\right), 1.75-1.64\left(\mathrm{~m}, 2 \mathrm{H}, \mathrm{NCHCH}{ }_{2}\right), 1.27-1.13\left(\mathrm{~m}, 2 \mathrm{H}, \mathrm{CH}_{2}\right), 1.01-$ 
$0.84\left(\mathrm{~m}, 2 \mathrm{H}, \mathrm{CH}_{2}\right)$. Spectroscopic data consistent with that reported in the literature. ${ }^{3}$ The crude product was used in the next step without further purification ( $\geq 95 \%$ purity by ${ }^{1} \mathrm{H}$ NMR spectroscopy).

\section{$(1 R, 2 R)-N^{1}, N^{2}$-Dimethyl- $N^{1}, N^{2}$-bis(3,3-dimethylbutyl)cyclohexane-1,2-diamine $(R, R)-4$}

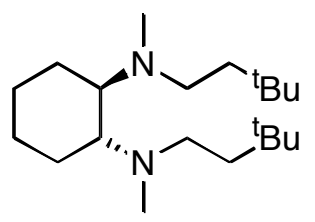

$(R, R)-4$

A solution of $t$-butylacetylchloride $(10.76 \mathrm{~mL}, 77.5 \mathrm{mmol})$ in $\mathrm{CH}_{2} \mathrm{Cl}_{2}(20 \mathrm{~mL})$ was added dropwise to a stirred biphasic mixture of crude diamine $(R, R)-6$ (max. $37.9 \mathrm{mmol})$ in $\mathrm{CH}_{2} \mathrm{Cl}_{2}(50 \mathrm{~mL})$ and $\mathrm{NaOH}(7.06$ $\mathrm{g}, 176.5 \mathrm{mmol})$ in water $(25 \mathrm{~mL})$ at $0{ }^{\circ} \mathrm{C}$ under air. The resulting mixture was stirred at $\mathrm{rt}$ for $40 \mathrm{~h}$. The two layers were separated and the aqueous layer was extracted with $\mathrm{CH}_{2} \mathrm{Cl}_{2}(5 \times 100 \mathrm{~mL})$. The combined organic extracts were dried $\left(\mathrm{K}_{2} \mathrm{CO}_{3}\right)$ and evaporated under reduced pressure to give the bis-amide as a white solid. A solution of the crude bis-amide in THF $(60 \mathrm{~mL})$ was added dropwise via a dropping funnel to a stirred suspension of $\mathrm{LiAlH}_{4}(7.20 \mathrm{~g}, 189.6 \mathrm{mmol})$ in $\mathrm{THF}(60 \mathrm{~mL})$ at $0{ }^{\circ} \mathrm{C}$ under $\mathrm{N}_{2}$. The resulting solution was stirred and heated at reflux for $40 \mathrm{~h}$. Then, the solution was cooled to $0{ }^{\circ} \mathrm{C}$ and $\mathrm{Et}_{2} \mathrm{O}(50 \mathrm{~mL})$ was added, followed by the portionwise addition of $\mathrm{Na}_{2} \mathrm{SO}_{4} \cdot 10 \mathrm{H}_{2} \mathrm{O}(36.0 \mathrm{~g})$. The resulting mixture was then stirred at $\mathrm{rt}$ for $1 \mathrm{~h}$. The solids were removed by filtration through a pad of Celite ${ }^{\circledR}$ and washed with 24:1 $\mathrm{CH}_{2} \mathrm{Cl}_{2}-\mathrm{MeOH}(2 \times 50 \mathrm{~mL})$. The combined organic extracts were dried $\left(\mathrm{K}_{2} \mathrm{CO}_{3}\right)$ and evaporated under reduced pressure to give the crude product as a yellow oil. Purification by Kügelrohr distillation gave diamine $(R, R)-6$ (8.42 g, 72\% over 4 steps) as a colourless oil, bp 180-190 ${ }^{\circ} \mathrm{C} / 1.5 \mathrm{~mm} \mathrm{Hg}$ (lit., ${ }^{2} 150{ }^{\circ} \mathrm{C} / 1.0$

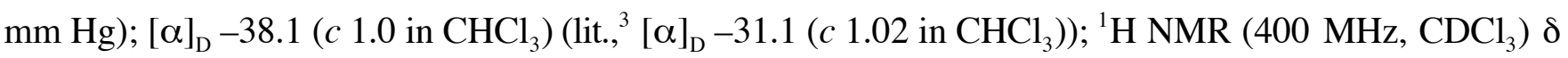
2.58-2.36 (m, 6H, $2 \times \mathrm{NCH}_{2}$ and $\left.2 \times \mathrm{NCH}\right), 2.25(\mathrm{~s}, 6 \mathrm{H}, 2 \times \mathrm{NMe}), 1.83-1.63\left(\mathrm{~m}, 4 \mathrm{H}, 2 \times \mathrm{NCHCH}_{2}\right), 1.39$ (t, $\left.J=8.0 \mathrm{~Hz}, 4 \mathrm{H}, 2 \times \mathrm{CH}_{2} \mathrm{CMe}_{3}\right), 1.20-1.06\left(\mathrm{~m}, 4 \mathrm{H}, 2 \times \mathrm{CH}_{2}\right), 0.90\left(\mathrm{~s}, 18 \mathrm{H}, 2 \times \mathrm{CMe}_{3}\right) ;{ }^{13} \mathrm{C} \mathrm{NMR}$ $\left(100.6 \mathrm{MHz}, \mathrm{CDCl}_{3}\right) \delta 62.6(\mathrm{NCH}), 50.1\left(\mathrm{NCH}_{2}\right), 42.2\left(\mathrm{CH}_{2} \mathrm{CMe}_{3}\right), 37.0(\mathrm{NMe}), 29.8\left(C \mathrm{Me}_{3}\right), 29.6$ $\left(\mathrm{CMe}_{3}\right), 25.9\left(\mathrm{CH}_{2}\right), 25.1\left(\mathrm{CH}_{2}\right)$, Spectroscopic data consistent with that reported in the literature. ${ }^{3}$ 
$(1 R, 2 R)-N^{1}, N^{2}$-Diisopropyl- $N^{1}, N^{2}$-dimethylcyclohexane-1,2-diamine $(R, R)$-2<smiles>CCCP(C)N(C)C1CCCCC1C</smiles>

$(R, R)-2$

Acetone (206 $\mu \mathrm{L}, 2.82 \mathrm{mmol})$ was added to a stirred solution of diamine $(R, R)-6(104 \mathrm{mg}, 0.73 \mathrm{mmol})$ in $\mathrm{CH}_{2} \mathrm{Cl}_{2}(3 \mathrm{~mL})$ at $\mathrm{rt}$ under $\mathrm{N}_{2}$. The resulting solution was stirred at $\mathrm{rt}$ for $5 \mathrm{~min}$ and $\mathrm{NaBH}(\mathrm{OAc})_{3}(604 \mathrm{mg}$, $2.83 \mathrm{mmol}$ ) was added portionwise over $5 \mathrm{~min}$. The resulting mixture was stirred at $\mathrm{rt}$ for $16 \mathrm{~h}$. Then, water ( $5 \mathrm{~mL})$ and $\mathrm{CH}_{2} \mathrm{Cl}_{2}(5 \mathrm{~mL})$ were added and the two layers were separated. The aqueous layer was extracted with $\mathrm{CH}_{2} \mathrm{Cl}_{2}(4 \times 5 \mathrm{~mL})$ and the combined organic extracts were dried $\left(\mathrm{MgSO}_{4}\right)$ and evaporated under reduced pressure to give the crude product as a colourless oil. A solution of the crude product in toluene (1 $\mathrm{mL}$ ) was added to a solution of $\mathrm{HCl}$ in $\mathrm{EtOH}$ (prepared by adding acetyl chloride (61 $\mu \mathrm{L}, 0.88 \mathrm{mmol})$ to EtOH $(389 \mu \mathrm{L}))$ at $0{ }^{\circ} \mathrm{C}$. Petrol was then added until a cloudy solution resulted. After $1 \mathrm{~h}$ at $0{ }^{\circ} \mathrm{C}$, the solid was collected by filtration and washed with petrol $(2 \times 2 \mathrm{~mL})$. The solid was dissolved in hexane $(5 \mathrm{~mL})$ and $2 \mathrm{M} \mathrm{NaOH}_{\text {(aq) }}(5 \mathrm{~mL})$ was added and the two layers were separated and the aqueous layer was extracted with hexane $(4 \times 5 \mathrm{~mL})$ and the combined organic extractss were dried $\left(\mathrm{MgSO}_{4}\right)$ and evaporated under reduced pressure to give diamine $(R, R)-2(122 \mathrm{mg}, 74 \%)$ as a colourless oil, ${ }^{1} \mathrm{H}$ NMR (400 MHz, $\left.\mathrm{CDCl}_{3}\right) \delta 2.93$ (septet, $J=6.5 \mathrm{~Hz}, 2 \mathrm{H}, 2 \times \mathrm{NCHMe}$ ), $2.65-2.56$ (m, $2 \mathrm{H}, 2 \times \mathrm{NCH}$ ), 2.20 (s, 6H, 2 x $\mathrm{NMe}), 1.81-1.71\left(\mathrm{~m}, 2 \mathrm{H}, 2 \times \mathrm{NCHCH}_{\mathrm{A}} \mathrm{H}_{\mathrm{B}}\right), 1.14-1.07\left(\mathrm{~m}, 2 \mathrm{H}, \mathrm{CH}_{2}\right), 1.06\left(\mathrm{~d}, J=6.5 \mathrm{~Hz}, 6 \mathrm{H}, \mathrm{CHMe} e_{2}\right)$, $\left.1.02(\mathrm{~d}, J=6.5 \mathrm{~Hz}, 6 \mathrm{H} \mathrm{CHMe})_{2}\right)$. Spectroscopic data consistent with that reported in the literature. ${ }^{4}$ Diamine $(R, R)-2$ was purified by Kügelrohr distillation before use: bp $180^{\circ} \mathrm{C} / 1.5 \mathrm{~mm} / \mathrm{Hg}$. 


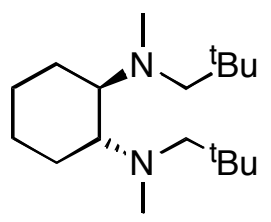

$(R, R)-3$

Trimethylacetaldehyde $(1.93 \mathrm{~mL}, 17.80 \mathrm{mmol})$ was added to a stirred solution of diamine $(R, R)-6$ (623 $\mathrm{mg}, 4.39 \mathrm{mmol})$ in $\mathrm{CH}_{2} \mathrm{Cl}_{2}(25 \mathrm{~mL})$ at rt under $\mathrm{N}_{2}$. The resulting solution was stirred at $\mathrm{rt}$ for $5 \mathrm{~min}$ and $\mathrm{NaBH}(\mathrm{OAc})_{3}(3.77 \mathrm{~g}, 17.80 \mathrm{mmol})$ was added portionwise over $5 \mathrm{~min}$. The resulting mixture was stirred at rt for $16 \mathrm{~h}$. Then, water $(30 \mathrm{~mL})$ and $\mathrm{CH}_{2} \mathrm{Cl}_{2}(20 \mathrm{~mL})$ were added and the two layers were separated and the aqueous layer was extracted with $\mathrm{CH}_{2} \mathrm{Cl}_{2}(4 \times 50 \mathrm{~mL})$ and the combined organic extracts were dried $\left(\mathrm{MgSO}_{4}\right)$ and evaporated under reduced pressure to give the crude product as a colourless oil. A solution of the crude product in toluene $(5 \mathrm{~mL})$ was added to a solution of $\mathrm{HCl}$ in $\mathrm{EtOH}$ (prepared by adding acetyl chloride $(364 \mu \mathrm{L}, 5.18 \mathrm{mmol})$ to $\mathrm{EtOH}(2.3 \mathrm{~mL}))$ at $0{ }^{\circ} \mathrm{C}$. Petrol was then added until a cloudy solution resulted. After $1 \mathrm{~h}$ at $0{ }^{\circ} \mathrm{C}$, the solid was collected by filtration and washed with petrol $(2 \times 5 \mathrm{~mL})$. The solid was dissolved in hexane $(20 \mathrm{~mL})$ and $2 \mathrm{M} \mathrm{NaOH}_{(\mathrm{aq})}(20 \mathrm{~mL})$ was added and the two layers were separated and the aqueous layer was extracted with hexane $(4 \times 20 \mathrm{~mL})$ and the combined organic extractss were dried $\left(\mathrm{MgSO}_{4}\right)$ and evaporated under reduced pressure to give diamine $(R, R)-3(777 \mathrm{mg}, 63 \%)$ as a colourless oil, ${ }^{1} \mathrm{H}$ NMR (400 MHz, $\mathrm{CDCl}_{3}$ ) $\delta$ 2.37-2.32 (m, 2H, 2 x NCH), 2.34-2.30 (m, 4H, $\mathrm{CH}_{2} \mathrm{CMe}_{3}$ ), $2.29\left(\mathrm{~s}, 6 \mathrm{H}, 2\right.$ x NMe), $1.78\left(\mathrm{br} \mathrm{dt}, J=13.5,3.0 \mathrm{~Hz}, 2 \mathrm{H}, \mathrm{NCHCH}_{\mathrm{A}} \mathrm{H}_{\mathrm{B}}\right), 1.71-1.62\left(\mathrm{~m}, 2 \mathrm{H}, \mathrm{NCHCH}_{\mathrm{A}} H_{\mathrm{B}}\right)$, 1.29-1.15 (m, 2H, $\left.2 \times \mathrm{CH}_{\mathrm{A}} \mathrm{H}_{\mathrm{B}}\right), 1.10-1.01\left(\mathrm{~m}, 2 \mathrm{H}, 2 \times \mathrm{CH}_{\mathrm{A}} H_{\mathrm{B}}\right), 0.89$ (s, 18H, $\left.2 \times \mathrm{CMe}_{3}\right)$. Spectroscopic data consistent with that reported in the literature. ${ }^{2}$ Diamine $(R, R)-\mathbf{3}$ was purified by Kügelrohr distillation before use: bp $210{ }^{\circ} \mathrm{C} / 2.5 \mathrm{~mm} / \mathrm{Hg}$ (lit., ${ }^{2} 120^{\circ} \mathrm{C} / 1 \mathrm{~mm} / \mathrm{Hg}$ ).

\section{General Procedure for lithiation/electrophilic trapping of $N$-Boc pyrrolidine 7}

$s$-BuLi (1.61 mL of a $1.27 \mathrm{M}$ solution in cyclohexane, $2.04 \mathrm{mmol}$ ) was added dropwise to a stirred solution of $\mathrm{N}$-Boc pyrrolidine $7(1.57 \mathrm{mmol})$ and the diamine $(1.75 \mathrm{mmol})$ in $\mathrm{Et}_{2} \mathrm{O}(5 \mathrm{~mL})$ at $-78{ }^{\circ} \mathrm{C}$ under Ar. The resulting solution was stirred at $-78{ }^{\circ} \mathrm{C}$ for $3 \mathrm{~h}$. Then, $\mathrm{Me}_{3} \mathrm{SiCl}(358 \mu \mathrm{L}, 2.82 \mathrm{mmol})$ was added 
dropwise and the reaction mixture was allowed to warm to rt and stirred at $\mathrm{rt}$ for $16 \mathrm{~h}$. Saturated $\mathrm{NH}_{4} \mathrm{Cl}_{(\mathrm{aq})}$ ( $5 \mathrm{~mL}$ ) was added and the mixture stirred for $20 \mathrm{~min}$ at $\mathrm{rt}$. The two layers were separated and the aqueous layer was extracted with $\mathrm{Et}_{2} \mathrm{O}(5 \times 5 \mathrm{~mL})$. The combined organic extracts were dried $\left(\mathrm{MgSO}_{4}\right)$ and evaporated under reduced pressure to give the crude product.

\section{(S)-2-Trimethylsilylpyrrolidine-1-carboxylic acid tert-butyl ester $(S)$-8}

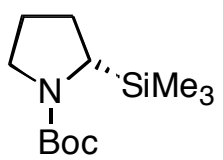

(S)-8

Using the general procedure for lithiation/electrophilic trapping, $s$-BuLi (1.05 mL of a $1.10 \mathrm{M}$ solution in cyclohexane, $1.16 \mathrm{mmol}), N$-Boc pyrrolidine 7 (157 $\mu \mathrm{L}, 0.90 \mathrm{mmol})$, diamine $(R, R)-4(361 \mathrm{mg}, 1.16 \mathrm{mmol})$ and $\mathrm{Me}_{3} \mathrm{SiCl}(252 \mu \mathrm{L}, 1.98 \mathrm{mmol})$ after $3 \mathrm{~h}$ lithiation in $\mathrm{Et}_{2} \mathrm{O}(3 \mathrm{~mL})$ gave the crude product as a yellow oil. Purification by flash column chromatography on silica with petrol-Et $\mathrm{E}_{2} \mathrm{O}(95: 5)$ as eluent gave pyrrolidine $(S)-8\left(166 \mathrm{mg}, 72 \%, 95: 5\right.$ er by chiral GC) as a colourless oil, $[\alpha]_{\mathrm{D}}+76.7\left(c 1.0 \mathrm{in} \mathrm{CHCl}_{3}\right)\left(\right.$ lit., ${ }^{5}$ $[\alpha]_{\mathrm{D}}^{20}+71.8\left(c\right.$ 2.6 in $\left.\mathrm{CHCl}_{3}\right)$ for $(S)-8$ of $98: 2$ er); $R_{\mathrm{F}}\left(95: 5\right.$ petrol-Et $\left.\mathrm{Et}_{2} \mathrm{O}\right) 0.3 ;{ }^{1} \mathrm{H}$ NMR $(400 \mathrm{MHz}$, $\mathrm{CDCl}_{3}$ ) $\delta$ 3.36-3.39 (br m, 1H, NCH), 3.38-3.06 (br m, 2H, $\mathrm{NCH}_{2}$ ), 2.12-1.92 (br m, 1H, $\mathrm{CH}_{\mathrm{A}} \mathrm{H}_{\mathrm{B}}$ ), 1.891.65 (br m, 3H, $\mathrm{CH}_{\mathrm{A}} H_{\mathrm{B}}$ and $\mathrm{CH}_{2}$ ), 1.47 (s, 9H, $\mathrm{CMe}_{3}$ ), 0.06 (s, 9H, SiMe ${ }_{3}$ ); GC: Betadex 120, $30 \mathrm{~m} \mathrm{x} 0.25$ mm i.d.( $\beta$-cyclodextrin) $\mathrm{T} 91{ }^{\circ} \mathrm{C}$ isothermal, He carrier gas at 12 psi constant pressure, 103 min $[(S)-8]$, $105 \min [(R)-8]$ and recovered $N$-Boc pyrrolidine $7(10 \mathrm{mg}, 7 \%)$ as a colourless oil. Spectroscopic data consistent with that reported in the literature. ${ }^{5}$

Using the general procedure for lithiation/electrophilic trapping, $s$-BuLi (560 $\mu \mathrm{L}$ of a $1.20 \mathrm{M}$ solution in cyclohexane, $0.67 \mathrm{mmol}), N$-Boc pyrrolidine $7(73 \mu \mathrm{L}, 0.42 \mathrm{mmol})$ and diamine $(R, R)-2(153 \mathrm{mg}, 0.67$ mmol) and $\mathrm{Me}_{3} \mathrm{SiCl}(189 \mu \mathrm{L}, 1.47 \mathrm{mmol})$ after $3 \mathrm{~h}$ lithiation in $\mathrm{Et}_{2} \mathrm{O}(2 \mathrm{~mL})$ gave the crude product as a yellow oil. Purification by flash column chromatography on silica with petrol-Et ${ }_{2} \mathrm{O}(95: 5)$ as eluent gave 
pyrrolidine $(S)-8(31 \mathrm{mg}, 29 \%, 50: 50$ er by chiral GC) as a colourless oil and recovered $N$-Boc pyrrolidine 7 (30 mg, 42\%) as a colourless oil.

Using the general procedure for lithiation/electrophilic trapping, $s$-BuLi $(710 \mu \mathrm{L}$ of a $1.20 \mathrm{M}$ solution in cyclohexane, $0.85 \mathrm{mmol}), N$-Boc pyrrolidine 7 (93 $\mu \mathrm{L}, 0.53 \mathrm{mmol})$, diamine $(R, R)-3$ (239 mg, $0.85 \mathrm{mmol})$, and $\mathrm{Me}_{3} \mathrm{SiCl}(160 \mu \mathrm{L}, 1.26 \mathrm{mmol})$ after $3 \mathrm{~h}$ in $\mathrm{Et}_{2} \mathrm{O}(2 \mathrm{~mL})$ gave the crude product as a yellow oil. Purification by flash column chromatography on silica with petrol-Et ${ }_{2} \mathrm{O}$ (95:5) as eluent gave pyrrolidine (S)-8 (4 mg, 4\%, 50:50 er by chiral GC) as a colourless oil and recovered $N$-Boc pyrrolidine 7 (47 mg, $51 \%)$ as a colourless oil.

\section{3-Phenylpropyl $N, N$-diisopropylcarbamate 9}

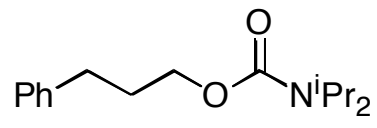

9

A solution of diisopropylcarbamoyl chloride $(2.16 \mathrm{~g}, 13.21 \mathrm{mmol})$ in $\mathrm{Et}_{2} \mathrm{O}(10 \mathrm{~mL})$ was added dropwise over $10 \mathrm{~min}$ to a stirred solution of $\mathrm{NaH}$ (579 mg of $60 \%$ wt dispersion in mineral oil, $14.47 \mathrm{mmol}$, prewashed with $\left.\mathrm{Et}_{2} \mathrm{O}(3 \times 10 \mathrm{~mL})\right)$ and 3-phenyl-1-propanol $(1.70 \mathrm{~mL}, 12.58 \mathrm{mmol})$ in $\mathrm{Et}_{2} \mathrm{O}(30 \mathrm{~mL})$ at $\mathrm{rt}$ under $\mathrm{N}_{2}$. The resulting mixture was stirred at $\mathrm{rt}$ for $16 \mathrm{~h}$. Then, $2 \mathrm{M} \mathrm{HCl}_{(\mathrm{aq})}(30 \mathrm{~mL})$ was added and the resulting mixture was stirred vigorously for $5 \mathrm{~min}$. The two layers were separated and the aqueous layer was extracted with $\mathrm{Et}_{2} \mathrm{O}(4 \times 30 \mathrm{~mL})$. The combined organic extracts were dried $\left(2: 1 \mathrm{Na}_{2} \mathrm{SO}_{4}-\mathrm{NaHCO}_{3}\right)$ and evaporated under reduced pressure to give the crude product as a yellow oil. Purification by flash column chromatography on silica with petrol-Et $\mathrm{E}_{2} \mathrm{O}(5: 1)$ as eluent gave carbamate $9(2.77 \mathrm{~g}, 84 \%)$ as a colourless oil; $R_{\mathrm{F}}(5: 1$ petrol-Et $2 \mathrm{O})$ 0.35; ${ }^{1} \mathrm{H}$ NMR (400 $\left.\mathrm{MHz}, \mathrm{CDCl}_{3}\right) \delta$ 7.33-7.27 (m, 2H, Ph), 7.23-7.17 (m, 3H, Ph), 4.28-3.58 (br m, 2 x NCH), 4.13 (t, $J=6.5 \mathrm{~Hz}, 2 \mathrm{H}, \mathrm{OCH}_{2}$ ), 2.73 (t, $J=8.0 \mathrm{~Hz}, 2 \mathrm{H}, \mathrm{CH}_{2} \mathrm{Ph}$ ), 2.03-1.95 (m, 2H, $\left.\mathrm{CH}_{2}\right), 1.23(\mathrm{~d}, J=7.0 \mathrm{~Hz}, 12 \mathrm{H}, 2 \times \mathrm{NCHMe} 2) ;{ }^{13} \mathrm{C} \mathrm{NMR}\left(100.6 \mathrm{MHz}, \mathrm{CDCl}_{3}\right) \delta 158.7$ 
$(\mathrm{C}=\mathrm{O}), 141.5\left(\right.$ ipso-Ph), $128.4(\mathrm{Ph}), 128.3(\mathrm{Ph}), 125.8(\mathrm{Ph}), 63.9\left(\mathrm{OCH}_{2}\right), 45.7(\mathrm{NCH}), 32.5\left(\mathrm{CH}_{2}\right), 30.8$

(Me), $21.0\left(\mathrm{CH}_{2}\right)$. Spectroscopic data consistent with that reported in the literature. ${ }^{6}$

\section{Diisopropylcarbamic acid $(S)$-1-hydroxymethyl-3-phenyl-propyl ester $(S)$-10}

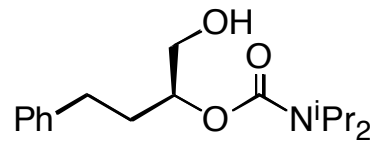

(S)-10

$s$-BuLi (1.38 mL of a $1.12 \mathrm{M}$ solution in cyclohexanes, $1.54 \mathrm{mmol})$ was added dropwise to a stirred solution of diamine $(S, S)-4(478 \mathrm{mg}, 1.54 \mathrm{mmol})$ in $\mathrm{Et}_{2} \mathrm{O}(2 \mathrm{~mL})$ at $-78{ }^{\circ} \mathrm{C}$ under Ar. After stirring for 30 min at $-78^{\circ} \mathrm{C}$, a solution of carbamate $9(279 \mathrm{mg}, 1.06 \mathrm{mmol})$ in $\mathrm{Et}_{2} \mathrm{O}(2 \mathrm{~mL})$ was added dropwise over 1 min. The resulting solution was stirred at $-78{ }^{\circ} \mathrm{C}$ for $5 \mathrm{~h}$. Then, a stream of $\mathrm{CO}_{2}$ was bubbled into the solution for $1 \mathrm{~h}$. The solution was then allowed to warm to rt over $10 \mathrm{~min}$. Water $(4 \mathrm{~mL})$ and concentrated $\mathrm{HCl}_{(\mathrm{aq})}(1 \mathrm{~mL})$ were added and the two layers were separated. The aqueous layer was extracted with EtOAc $(3 \times 10 \mathrm{~mL})$ and the combined organic extracts were dried $\left(\mathrm{MgSO}_{4}\right)$ and evaporated under reduced pressure to give the crude acid as a colourless oil. $\mathrm{BH}_{3} \cdot \mathrm{DMS}(3.50 \mathrm{~mL}$ of a $2 \mathrm{M}$ solution in THF, 7.00 mmol) was added dropwise over 2 min to a stirred solution of the crude acid (max. $1.06 \mathrm{mmol}$ ) at $0{ }^{\circ} \mathrm{C}$ under Ar. The resulting solution was allowed to warm to rt over $15 \mathrm{~min}$ and stirred at $\mathrm{rt}$ for $16 \mathrm{~h}$. Then, the solution was cooled to $0{ }^{\circ} \mathrm{C}$ and $\mathrm{MeOH}(20 \mathrm{~mL})$ was added over $10 \mathrm{~min}$. The resulting solution was then stirred at $\mathrm{rt}$ for $1 \mathrm{~h}$ and then stirred and heated at reflux for $1 \mathrm{~h}$. After being allowed to cool to rt, the solvent was evaporated under reduced pressure to give the crude product as a yellow oil. Purification by flash column chromatography on silica with petrol-EtOAc (1:1) as eluent gave alcohol $(S)-\mathbf{1 0}(259 \mathrm{mg}, 84 \%$, 84:16 er by chiral HPLC of the diol obtained after $\mathrm{LiAlH}_{4}$ reduction) as a white solid, mp 56-57 ${ }^{\circ} \mathrm{C}$, (lit., ${ }^{6}$ $\left.55-57{ }^{\circ} \mathrm{C}\right) ; R_{\mathrm{F}}\left(1: 1\right.$ petrol-EtOAc) $0.3 ;[\alpha]_{\mathrm{D}}-20.7\left(\right.$ c 1.0 in $\left.\mathrm{CHCl}_{3}\right) ;{ }^{1} \mathrm{H}$ NMR $\left(400 \mathrm{MHz}, \mathrm{CDCl}_{3}\right) \delta 7.33-$ 7.26 (m, 2H, Ph), 7.24-7.16 (m, 3H, Ph), 4.93-4.84 (m, 1H, CHO), 4.19-4.00 (m, 2H, CHMe $)_{2}, 3.76$ (dd, J $\left.=12.0,3.0 \mathrm{~Hz}, 1 \mathrm{H}, \mathrm{CH}_{\mathrm{A}} \mathrm{H}_{\mathrm{B}} \mathrm{OH}\right), 3.69$ (dd, $\left.J=12.0,3.0 \mathrm{~Hz}, 1 \mathrm{H}, \mathrm{CH}_{\mathrm{A}} H_{\mathrm{B}} \mathrm{OH}\right), 2.80-2.64\left(\mathrm{~m}, 2 \mathrm{H}, \mathrm{CH}_{2} \mathrm{Ph}\right)$, 2.01-1.82 (m, 2H, $\left.\mathrm{CH}_{2}\right), 1.25$ (d, $J=7.0 \mathrm{~Hz}, 12 \mathrm{H}, 4$ x CHMe); ${ }^{13} \mathrm{C} \mathrm{NMR}\left(100.6 \mathrm{MHz}, \mathrm{CDCl}_{3}\right) \delta 156.5$ $(\mathrm{C}=\mathrm{O}), 141.4\left(\right.$ ipso-Ph), $128.5(\mathrm{Ph}), 128.3(\mathrm{Ph}), 126.1(\mathrm{Ph}), 76.4(\mathrm{CHO}), 66.2\left(\mathrm{CH}_{2} \mathrm{O}\right), 46.3(\mathrm{CHN}), 45.6$ 
$\left.(\mathrm{CHN}), 33.1\left(\mathrm{CH}_{2}\right), 31.9\left(\mathrm{CH}_{2}\right) \cdot 21.3\left(\mathrm{CHMe}_{2}\right) 20.6(\mathrm{CHMe})_{2}\right)$. Spectroscopic data consistent with that reported in the literature. ${ }^{6}$

\section{(S)-4-Phenylbutane-1,2-diol}<smiles>OCC(O)CCc1ccccc1</smiles>

$\mathrm{LiAlH}_{4}(175 \mathrm{mg}, 4.55 \mathrm{mmol})$ was added portionwise to a stirred solution of alcohol $(S)-\mathbf{1 0}(259 \mathrm{mg}, 0.89$ $\mathrm{mmol})$ in THF $(20 \mathrm{~mL})$ at $0{ }^{\circ} \mathrm{C}$ under Ar. The resulting solution was stirred and heated at reflux for $18 \mathrm{~h}$. After being allowed to cool to rt, the solution was cooled to $0{ }^{\circ} \mathrm{C}$ and $\mathrm{Na}_{2} \mathrm{SO}_{4} \cdot 10 \mathrm{H}_{2} \mathrm{O}(1.0 \mathrm{~g})$ was added portionwise. The resulting suspension was then stirred at $\mathrm{rt}$ for $1 \mathrm{~h}$. The solids were removed by filtration through a pad of Celite ${ }^{\circledR}$ and washed with $\mathrm{CH}_{2} \mathrm{Cl}_{2}(25 \mathrm{~mL}), 1: 1 \mathrm{CH}_{2} \mathrm{Cl}_{2}-\mathrm{MeOH}(25 \mathrm{~mL})$ and $\mathrm{MeOH}(25$ $\mathrm{mL}$ ). The combined organic extracts were evaporated under reduced pressure to give the crude product as a white oil. Purification by flash column chromatography on silica with $\mathrm{CH}_{2} \mathrm{Cl}_{2}-\mathrm{MeOH}(19: 1)$ as eluent gave (S)-4-phenylbutane-1,2-diol (73 mg, 50\%, 84:16 er by chiral HPLC) as a colourless oil, $R_{\mathrm{F}}\left(19: 1 \mathrm{CH}_{2} \mathrm{Cl}_{2}\right.$ $\mathrm{MeOH})$ 0.2; ${ }^{1} \mathrm{H}$ NMR (400 MHz, $\mathrm{CDCl}_{3}$ ) $\delta$ 7.31-7.28 (m, 2H, Ph), 7.23-7.19 (m, 3H, Ph), 3.75-3.69 (m, $1 \mathrm{H}, \mathrm{CHOH}), 3.65\left(\mathrm{dd}, J=11.0,3.0 \mathrm{~Hz}, 1 \mathrm{H}, \mathrm{CH}_{\mathrm{A}} \mathrm{H}_{\mathrm{B}} \mathrm{OH}\right), 3.46\left(\mathrm{dd}, J=11.0,7.5 \mathrm{~Hz}, 1 \mathrm{H}, \mathrm{CH}_{\mathrm{A}} H_{\mathrm{B}} \mathrm{OH}\right)$, 2.83-2.65 (m, 2H), 1.79-1.72 (m, 2H); Chiral HPLC: Daicel Chiralcel OD, 1:4 v/v iPrOH-hexane, $0.5 \mathrm{~mL}$ $\min ^{-1}, 254 \mathrm{~nm}, 14.5 \mathrm{~min}[(R)] 18.5 \min [(S)]$. Spectroscopic data consistent with that reported in the literature. $^{6}$ 


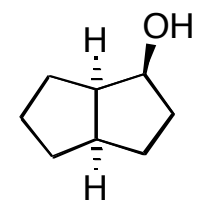

12

$s$-BuLi (1.46 mL of a 1.12 M solution in cyclohexanes, $1.64 \mathrm{mmol})$ was added dropwise to a stirred solution of diamine $(R, R)-4(507 \mathrm{mg}, 1.64 \mathrm{mmol})$ in $\mathrm{Et}_{2} \mathrm{O}(2 \mathrm{~mL})$ at $-78{ }^{\circ} \mathrm{C}$ under Ar. The resulting solution was stirred at $-78{ }^{\circ} \mathrm{C}$ for $30 \mathrm{~min}$ and then a solution of cyclooctene oxide $\mathbf{1 1}$ (154 $\left.\mathrm{mg}, 1.22 \mathrm{mmol}\right)$ in $\mathrm{Et}_{2} \mathrm{O}(2 \mathrm{~mL})$ was added dropwise over 2 min. The resulting solution was stirred at $-78{ }^{\circ} \mathrm{C}$ for $5 \mathrm{~h}$ and then allowed to warm to $\mathrm{rt}$ and stirred at $\mathrm{rt}$ for $16 \mathrm{~h}$. The solution was cooled to $0{ }^{\circ} \mathrm{C}$ and $2 \mathrm{M} \mathrm{HCl}_{\text {(aq) }}(10$ $\mathrm{mL})$ was added. The two layers were separated and the aqueous layer was extracted with EtOAc (4 x 10 $\mathrm{mL})$. The combined organic extracts were washed with saturated $\mathrm{NaHCO}_{3(\mathrm{aq})}(10 \mathrm{~mL})$, dried $\left(\mathrm{MgSO}_{4}\right)$ and evaporated under reduced pressure to give the crude product as a colourless oil. Purification by flash column chromatography on silica with petrol-Et ${ }_{2} \mathrm{O}(7: 3)$ as eluent gave alcohol 12 (141 mg, 92\%, 50:50 er by chiral HPLC of the dinitrobenzoate) as a colourless oil, $R_{\mathrm{F}}\left(1: 1\right.$ petrol-Et $\left.{ }_{2} \mathrm{O}\right) 0.3 ;{ }^{1} \mathrm{H} \mathrm{NMR}(400 \mathrm{MHz}$, $\left.\mathrm{CDCl}_{3}\right) \delta 4.17-4.13(\mathrm{~m}, 1 \mathrm{H}, \mathrm{CHOH}), 2.45-2.35$ (m, 2H, 2 x CH), 1.81-1.07 (m, 11H, 5 x $\mathrm{CH}_{2}$ and $\left.\mathrm{OH}\right)$. Spectroscopic data consistent with that reported in the literature. ${ }^{7}$

\section{2,4-Dinitro-benzoic acid (S)-(octahydro-pentalen-1-yl) ester}

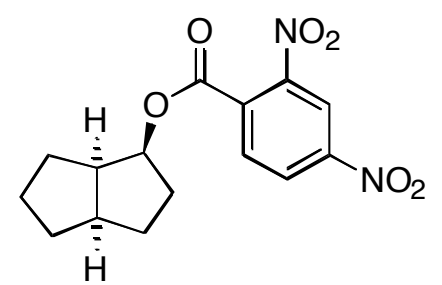

2,4-Dinitrobenzoic acid (170 mg, $0.81 \mathrm{mmol})$ was added in one portion to a stirred solution of alcohol 12 (68 mg, $0.54 \mathrm{mmol}$ ), DMAP (6 mg, $0.05 \mathrm{mmol})$ and DCC (133 mg, $0.65 \mathrm{mmol})$ in $\mathrm{CH}_{2} \mathrm{Cl}_{2}(5 \mathrm{~mL})$ under Ar at $0{ }^{\circ} \mathrm{C}$. The resulting solution was stirred at $\mathrm{rt}$ for $72 \mathrm{~h}$. Then, the solids were removed by filtration and washed with $\mathrm{CH}_{2} \mathrm{Cl}_{2}(2 \times 5 \mathrm{~mL})$. The combined filtrate was evaporated to give the crude product as a 
yellow solid. Purification by flash column chromatography on silica with petrol-Et ${ }_{2} \mathrm{O}(3: 2)$ as eluent the gave ester (167 mg, 97\%, 50:50 er by chiral HPLC) as a yellow oil, $R_{\mathrm{F}}\left(1: 1\right.$ petrol-Et $\left.{ }_{2} \mathrm{O}\right) 0.8 ;{ }^{1} \mathrm{H}$ NMR (400 $\left.\mathrm{MHz} \mathrm{CDCl}_{3}\right) \delta 8.76(\mathrm{~d}, J=2.0 \mathrm{~Hz}, 1 \mathrm{H}, \mathrm{ArCH}), 8.53(\mathrm{dd}, J=8.5,2.0 \mathrm{~Hz}, 1 \mathrm{H}, \mathrm{ArCH}), 7.96(\mathrm{~d}, J=8.5 \mathrm{~Hz}$, $1 \mathrm{H}, \mathrm{ArCH}), 5.37(\mathrm{dd}, J=12.5,6.5 \mathrm{~Hz}, 1 \mathrm{H}, \mathrm{CHO}), 2.28-2.67$ (m, 1H, CH), 2.59-2.46 (m, 1H, CH), $1.98-$ 1.19 (m, 10H, $\mathrm{CH}_{2}$ ); Chiral HPLC: Daicel Chiralpak AD-H, 3:7 v/v MeOH-hexane + 0.2\% iPrOH, $5 \mathrm{~mL}$ $\min ^{-1}, 254 \mathrm{~nm}, 0.92 \mathrm{~min}$ and $1.63 \mathrm{~min}(e n t)$. Spectroscopic data consistent with that reported in the literature. $^{7}$

\section{tert-Butyldimethylphosphine borane 13}

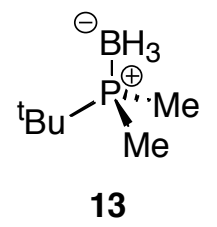

$\mathrm{MeMgBr}\left(46.5 \mathrm{~mL}\right.$ of a $3 \mathrm{M}$ solution in $\left.\mathrm{Et}_{2} \mathrm{O}, 139.6 \mathrm{mmol}\right)$ was added dropwise over $1 \mathrm{~h}$ to a stirred solution of $t$-butyldichlorophosphine $(10.0 \mathrm{~g}, 62.9 \mathrm{mmol})$ in $\mathrm{THF}(120 \mathrm{~mL})$ at $-10{ }^{\circ} \mathrm{C}$ under Ar. The resulting cloudy solution was stirred at $\mathrm{rt}$ for $5 \mathrm{~h}$ and then cooled to $-10{ }^{\circ} \mathrm{C}$. Then, $\mathrm{BH}_{3} \bullet \mathrm{DMS}(38.0 \mathrm{~mL}$ of a $2 \mathrm{M}$ solution in THF, $76.0 \mathrm{mmol}$ ) was added dropwise over $20 \mathrm{~min}$. The solution was stirred at $\mathrm{rt}$ for $1 \mathrm{~h}$ and poured onto a mixture of ice $(150 \mathrm{~g})$ and concentrated $\mathrm{HCl}_{(\mathrm{aq})}(15 \mathrm{~mL})$. The mixture was extracted with EtOAc $(4 \times 50 \mathrm{~mL})$ and the combined organic extracts were dried $\left(\mathrm{MgSO}_{4}\right)$ and evaporated under reduced pressure to give the crude product as a white solid. Purification by recrystallisation from hexane $(40 \mathrm{~mL})$ gave phosphine borane $13(6.12 \mathrm{~g}, 74 \%)$ as a white solid, mp $163-164{ }^{\circ} \mathrm{C}$ (lit., $\left.{ }^{8} 160-163{ }^{\circ} \mathrm{C}\right) ; R_{\mathrm{F}}(4: 1$ petrol$\left.\mathrm{Et}_{2} \mathrm{O}\right)$ 0.4; ${ }^{1} \mathrm{H} \mathrm{NMR}\left(400 \mathrm{MHz}, \mathrm{CDCl}_{3}\right) \delta 1.21(\mathrm{~d}, J=10.0 \mathrm{~Hz}, 6 \mathrm{H}, \mathrm{PMe}), 1.13(\mathrm{~d}, J=14.0 \mathrm{~Hz}, 9 \mathrm{H}$, $\left.\mathrm{CMe}_{3}\right), 0.41\left(\mathrm{qd}, J=95.0,13.0 \mathrm{~Hz}, 3 \mathrm{H}, \mathrm{BH}_{3}\right)$. Spectroscopic data consistent with that reported in the literature. $^{8}$ 


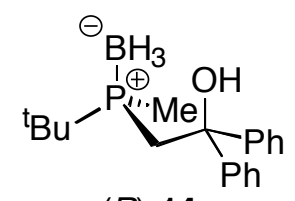

(R)-14

$s$-BuLi (1.00 mL of a 1.12 M solution in cyclohexanes, $1.49 \mathrm{mmol})$ was added dropwise to a stirred solution of diamine $(S, S)-4(464 \mathrm{mg}, 1.49 \mathrm{mmol})$ in $\mathrm{Et}_{2} \mathrm{O}(2 \mathrm{~mL})$ at $-78{ }^{\circ} \mathrm{C}$ under Ar. The resulting solution was stirred at $-78{ }^{\circ} \mathrm{C}$ for $30 \mathrm{~min}$ and then a solution of phosphine borane $\mathbf{1 3}$ (138 $\left.\mathrm{mg}, 1.05 \mathrm{mmol}\right)$ in $\mathrm{Et}_{2} \mathrm{O}(2 \mathrm{~mL})$ was added dropwise over $2 \mathrm{~min}$. The resulting solution was stirred at $-78^{\circ} \mathrm{C}$ for $3 \mathrm{~h}$. Then, a solution of benzophenone $(229 \mathrm{mg}, 1.29 \mathrm{mmol})$ in $\mathrm{Et}_{2} \mathrm{O}(1 \mathrm{~mL})$ was added dropwise. The resulting mixture was allowed to warm to $\mathrm{rt}$ and stirred at $\mathrm{rt}$ for $16 \mathrm{~h} .1 \mathrm{M} \mathrm{HCl}_{(\mathrm{aq})}(2 \mathrm{~mL})$ was added and the two layers were separated. The aqueous layer was extracted with $\mathrm{Et}_{2} \mathrm{O}(5 \times 5 \mathrm{~mL})$ and the combined organic extracts were dried $\left(\mathrm{MgSO}_{4}\right)$ and evaporated under reduced pressure to give the crude product as a white solid. Purification by flash column chromatography on silica with petrol-EtOAc (95:5) as eluent gave alcohol $(R)-14$ (309 mg, 99\%, 60:40 er by chiral HPLC) as a white solid, mp 110-112 ${ }^{\circ} \mathrm{C}$ (lit., ${ }^{9}$ 116.5-117.5 $\left.{ }^{\circ} \mathrm{C}\right) ; R_{\mathrm{F}}\left(95: 5\right.$ petrol-EtOAc) $0.2 ;[\alpha]_{\mathrm{D}}-2.5\left(c 1.0\right.$ in $\left.\mathrm{CHCl}_{3}\right)$ (lit., ${ }^{9}[\alpha]_{\mathrm{D}}-14.9\left(c 0.47\right.$ in $\mathrm{CHCl}_{3}$ ) for $(R)-14$ of 96:4 er); ${ }^{1} \mathrm{H}$ NMR (400 MHz, $\mathrm{CDCl}_{3}$ ) $\delta$ 7.55-7.44 (m, 4H, Ph), 7.38-7.28 (m, 4H, Ph), 7.28-7.20 (m, $2 \mathrm{H}, \mathrm{Ph}), 4.58(\mathrm{~s}, 1 \mathrm{H}, \mathrm{OH}), 2.89\left(\mathrm{t}, J=14.5 \mathrm{~Hz}, 1 \mathrm{H} \mathrm{C}(\mathrm{OH}) \mathrm{CH}_{\mathrm{A}} \mathrm{H}_{\mathrm{B}}\right), 2.68(\mathrm{dd}, J=14.5,7.0 \mathrm{~Hz}, 1 \mathrm{H}$ $\left.\mathrm{C}(\mathrm{OH}) \mathrm{CH}_{\mathrm{A}} H_{\mathrm{B}}\right), 1.80\left(\mathrm{~d}, J=13.5 \mathrm{~Hz}, 9 \mathrm{H}, \mathrm{CMe}_{3}\right), 1.07-0.07\left(\mathrm{~m}, 3 \mathrm{H}, \mathrm{BH}_{3}\right), 0.75(\mathrm{~d}, J=10.0 \mathrm{~Hz}, 3 \mathrm{H}, \mathrm{PMe})$; Chiral HPLC: Daicel Chiralcel OD, 1:19 v/v $i$-PrOH-hexane, $0.5 \mathrm{~mL} \mathrm{~min}^{-1}, 254 \mathrm{~nm}, 10.5 \mathrm{~min}[(R)-14] 12.5$ $\min [(S)-14]$. Spectroscopic data consistent with that reported in the literature. ${ }^{10}$ 


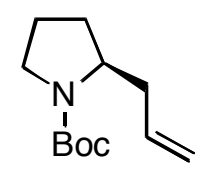

15

$s$-BuLi (0.98 mL of a 1.20 M solution in cyclohexane, $1.18 \mathrm{mmol})$ was added dropwise over $1 \mathrm{~min}$ to a stirred solution of the $N$-Boc pyrrolidine $7(160 \mu \mathrm{L}, 0.91 \mathrm{mmol})$ and diamime $(S, S)-4(366 \mu \mathrm{L}, 1.18 \mathrm{mmol})$ in $\mathrm{Et}_{2} \mathrm{O}(3.5 \mathrm{~mL})$ at $-78{ }^{\circ} \mathrm{C}$ under Ar. The resulting solution was stirred at $-78{ }^{\circ} \mathrm{C}$ for $3 \mathrm{~h}$. Then, $\mathrm{CuCN} \cdot 2 \mathrm{LiCl}(758 \mu \mathrm{L}$ of a $0.6 \mathrm{M}$ solution in THF, $0.46 \mathrm{mmol})$ was added dropwise and the resulting solution was stirred at $-78{ }^{\circ} \mathrm{C}$ for $1 \mathrm{~h}$. Then, allyl bromide $(142 \mu \mathrm{L}, 1.64 \mathrm{mmol})$ was added dropwise and the reaction mixture was allowed to warm to $\mathrm{rt}$ and stirred at $\mathrm{rt}$ for $16 \mathrm{~h}$. $\mathrm{NH}_{4} \mathrm{OH}_{(\mathrm{aq})}(0.5 \mathrm{~mL})$, saturated $\mathrm{NH}_{4} \mathrm{Cl}_{(\mathrm{aq})}(4.5 \mathrm{~mL})$ and $\mathrm{Et}_{2} \mathrm{O}(5 \mathrm{~mL})$ were added and the mixture stirred at $\mathrm{rt}$ for $20 \mathrm{~min}$. The solids were removed by filtration through a pad of Celite ${ }^{\circledR}$ and the filter cake was washed with $\mathrm{Et}_{2} \mathrm{O}(5 \mathrm{~mL})$. The two layers of the filtrate were separated and the blue aqueous layer was extracted with $\mathrm{Et}_{2} \mathrm{O}(3 \times 20 \mathrm{~mL})$. The combined organic extracts were dried $\left(\mathrm{MgSO}_{4}\right)$ and evaporated under reduced pressure to give the crude product. Purification by flash column chromatography on silica with petrol-EtOAc (85:15) as eluent gave allyl pyrrolidine 15 (150 mg, 78\%, 85:15 er by chiral HPLC) as a colourless oil, $R_{\mathrm{F}}(9: 1$ petrol-EtOAc) 0.2; $[\alpha]_{D}^{24}-35.1\left(c 0.95\right.$ in $\mathrm{CHCl}_{3}$ ) (lit., ${ }^{11}[\alpha]^{24}-32.4\left(c 1.56\right.$ in $\mathrm{CHCl}_{3}$ ) for $(S)-\mathbf{1 5}$ of $\geq 99: 1$ er); ${ }^{1} \mathrm{H}$ NMR $\left(400 \mathrm{MHz}, \mathrm{CDCl}_{3}\right) \delta 5.74\left(\mathrm{ddt}, J=17.5,10.0,7.0 \mathrm{~Hz}, 1 \mathrm{H}, \mathrm{CH}=\mathrm{CH}_{2}\right), 5.05(\mathrm{~d}, J=17.5 \mathrm{~Hz}, 1 \mathrm{H}$, trans$\left.\mathrm{CH}=\mathrm{CH}_{\mathrm{A}} \mathrm{H}_{\mathrm{B}}\right), 5.03\left(\mathrm{~d}, J=10.0 \mathrm{~Hz}, 1 \mathrm{H}\right.$, cis $\left.-\mathrm{CH}=\mathrm{CH}_{\mathrm{A}} H_{\mathrm{B}}\right), 3.88-3.73($ br m, $1 \mathrm{H}, \mathrm{CHN}), 3.41-3.36(\mathrm{~m}, 2 \mathrm{H}$, $\left.\mathrm{CH}_{2} \mathrm{~N}\right), 2.55-2.42\left(\mathrm{~m}, 1 \mathrm{H}, \mathrm{CH}_{\mathrm{A}} \mathrm{H}_{\mathrm{B}} \mathrm{CH}=\mathrm{CH}_{2}\right), 2.16-2.05\left(\mathrm{~m}, 1 \mathrm{H}, \mathrm{CH}_{\mathrm{A}} \mathrm{H}_{\mathrm{B}} \mathrm{CH}=\mathrm{CH}_{2}\right), 1.94-1.66(\mathrm{~m}, 4 \mathrm{H}, 2 \mathrm{x}$ $\mathrm{CH}_{2}$ ), 1.46 (s, 9H, $\mathrm{CMe}_{3}$ ); Chiral HPLC: Chiralcel OD, 99:1 hexane:i-PrOH, $0.1 \mathrm{mLmin}^{-1}, 44.07$ min [(R)15], $47.38 \min [(S)-15]$. Spectroscopic data consistent with that reported in the literature. ${ }^{12}$ 


\section{(S)-Benzyl 2-allylpyrrolidine-1-carboxylate 16}

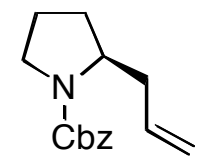

16

TFA (1 mL, $13.46 \mathrm{mmol})$ was added dropwise to a stirred solution of pyrrolidine $(S)$-15 (145 mg, 0.69 mmol) in $\mathrm{CH}_{2} \mathrm{Cl}_{2}(5 \mathrm{~mL})$ at $\mathrm{rt}$ under Ar. The resulting solution was stirred at $\mathrm{rt}$ for $3 \mathrm{~h}$ and the solvent was evaporated under reduced pressure to give the crude product as a yellow oil. To a stirred solution of the crude product in $\mathrm{CH}_{2} \mathrm{Cl}_{2}(2 \mathrm{~mL})$ at $0{ }^{\circ} \mathrm{C}$ under $\mathrm{Ar}, \mathrm{Et}_{3} \mathrm{~N}(288 \mu \mathrm{L}, 2.07 \mathrm{mmol})$ and benzyl chloroformate $(128 \mu \mathrm{L}, 0.90 \mathrm{mmol})$ were added dropwise. The resulting mixture was allowed to warm to $\mathrm{rt}$ and stirred at rt for $8 \mathrm{~h} . \mathrm{CH}_{2} \mathrm{Cl}_{2}(5 \mathrm{~mL})$ and water $(5 \mathrm{~mL})$ were added and the two layers were separated. The aqueous layer was extracted with $\mathrm{CH}_{2} \mathrm{Cl}_{2}(4 \times 10 \mathrm{~mL})$ and the combined organic extracts were dried $\left(\mathrm{MgSO}_{4}\right)$ and evaporated under reduced pressure to give the crude product as a yellow oil. Purification by flash column chromatography on silica with petrol-EtOAc (9:1) as eluent gave allyl pyrrolidine $(S)-16$ (168 mg, 99\% over 2 steps) as a colourless oil, $[\alpha]_{\mathrm{D}}^{24}-30.2$ (c 1.15 in $\mathrm{CHCl}_{3}$ ) (lit., ${ }^{13}[\alpha]_{\mathrm{D}}^{24}-38.7$ (c 1.13 in $\mathrm{CHCl}_{3}$ ) for $(S)$-16 of $\geq 99: 1$ er); $R_{\mathrm{F}}\left(9: 1\right.$ petrol-EtOAc) $0.3 ;{ }^{1} \mathrm{H} \mathrm{NMR}\left(400 \mathrm{MHz}, \mathrm{CDCl}_{3}\right)$ rotamers present $\delta$ 7.41-7.28 (m, 5H, Ph), 5.84-5.64 (m, 1H, $\left.\mathrm{CH}=\mathrm{CH}_{2}\right), 5.23-4.97\left(\mathrm{~m}, 4 \mathrm{H}, \mathrm{CH}=\mathrm{CH}_{2}\right.$ and $\left.\mathrm{CH}_{2} \mathrm{Ph}\right), 3.98-3.85(\mathrm{~m}, 1 \mathrm{H}$, $\mathrm{NCH}), \quad 3.53-3.36\left(\mathrm{~m}, \quad 2 \mathrm{H}, \quad \mathrm{NCH}_{2}\right), \quad 2.65-2.39\left(\mathrm{~m}, \quad 1 \mathrm{H}, \quad \mathrm{CH}_{\mathrm{A}} \mathrm{H}_{\mathrm{B}} \mathrm{CH}=\mathrm{CH}_{2}\right), \quad 2.23-2.08 \quad(\mathrm{~m}, \quad 1 \mathrm{H}$, $\left.\mathrm{CH}_{\mathrm{A}} \mathrm{H}_{\mathrm{B}} \mathrm{CH}=\mathrm{CH}_{2}\right), 1.99-1.70\left(\mathrm{~m}, 4 \mathrm{H}, 2 \times \mathrm{CH}_{2}\right) ;{ }^{13} \mathrm{C} \mathrm{NMR}\left(100.6 \mathrm{MHz}, \mathrm{CDCl}_{3}\right)$ approx 1:1 mixture of rotamers, $\delta 154.9$ and $154.7(\mathrm{C}=\mathrm{O}), 137.1$ and 136.9 (ipso-Ph), 135.0 and $134.8\left(C \mathrm{H}=\mathrm{CH}_{2}\right), 128.4$ and 127.8 and $127.7(\mathrm{Ph}), 117.3$ and $117.2\left(\mathrm{CH}=\mathrm{CH}_{2}\right), 66.6$ and $66.4\left(\mathrm{CH}_{2} \mathrm{Ph}\right), 57.2$ and $56.7(\mathrm{NCH}), 46.8$ and $46.5\left(\mathrm{NCH}_{2}\right), 38.9$ and $38.0\left(\mathrm{CH}_{2} \mathrm{CH}=\mathrm{CH}_{2}\right), 30.0$ and $29.1\left(\mathrm{CH}_{2}\right), 23.6$ and $22.8\left(\mathrm{CH}_{2}\right)$. Spectroscopic data consistent with that reported in the literature. ${ }^{13}$ 


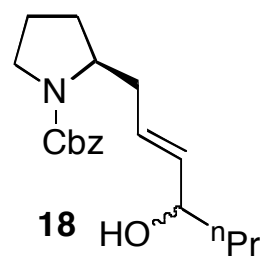

Grubbs' 2nd generation catalyst (28 $\mathrm{mg}, 0.033 \mathrm{mmol}$ ) was added in one portion to a stirred solution of the allyl-pyrrolidine 16 (160 mg, $0.65 \mathrm{mmol})$ and 1-hexen-3-ol 17 (157 $\mu \mathrm{L}, 1.31 \mathrm{mmol})$ in $\mathrm{CH}_{2} \mathrm{Cl}_{2}(4.5$ $\mathrm{mL}$ ) at $\mathrm{rt}$ under Ar. The resulting mixture was stirred at $\mathrm{rt}$ for $6 \mathrm{~h}$ before a second portion of Grubb's 2nd generation catalyst (10 mg, $0.012 \mathrm{mmol}$ ) was added. The resulting mixture was stirred at rt for a further 10 h. Then, the solvent was removed under reduced pressure to give the crude product as a brown oil. Purification by flash column chromatography on silica with petrol-EtOAc (7:3 to 1:1) as eluent gave alcohol $18(161 \mathrm{mg}, 78 \%)$ as a yellow oil, $R_{\mathrm{F}}(1: 1$ petrol-EtOAc) 0.53; IR (neat) $3435(\mathrm{OH}), 1695(\mathrm{C}=\mathrm{O})$, $1425(\mathrm{C}=\mathrm{C}) \mathrm{cm}^{-1} ;{ }^{1} \mathrm{H} \mathrm{NMR}\left(400 \mathrm{MHz}, \mathrm{CDCl}_{3}\right)$ mixture of diastereoisomers/rotamers $\delta$ 7.43-7.25 (m, 5H, $\mathrm{Ph})$, 5.68-5.36 (m, 2H, CH=CH), 5.23-5.04 (m, 2H, $\left.\mathrm{CH}_{2} \mathrm{Ph}\right), 4.10-3.97(\mathrm{~m}, 1 \mathrm{H}, \mathrm{CHOH}), 3.97-3.81$ (m, $1 \mathrm{H}, \mathrm{NCH}), 3.53-3.31\left(\mathrm{~m}, 2 \mathrm{H}, \mathrm{NCH}_{2}\right), 2.57-2.32\left(\mathrm{~m}, 1 \mathrm{H}, \quad \mathrm{CH}_{\mathrm{A}} \mathrm{H}_{\mathrm{B}} \mathrm{CH}=\mathrm{CH}\right), 2.23-2.05(\mathrm{~m}, 1 \mathrm{H}$, $\left.\mathrm{CH}_{\mathrm{A}} \mathrm{H}_{\mathrm{B}} \mathrm{CH}=\mathrm{CH}\right), 1.98-1.67\left(\mathrm{~m}, 4 \mathrm{H}, 2 \times \mathrm{CH}_{2}\right), 1.58-1.21\left(\mathrm{~m}, 4 \mathrm{H}, 2 \times \mathrm{CH}_{2}\right), 0.92$ (t, $\left.J=7.5 \mathrm{~Hz}, 3 \mathrm{H}, \mathrm{Me}\right)$; ${ }^{13} \mathrm{C}$ NMR (400 MHz, $\mathrm{CDCl}_{3}$ ) mixture diastereoisomers/rotamers $\delta 154.9(\mathrm{C}=\mathrm{O}), 137.0$ (ipso-Ph), 136.1 and $136.0(=\mathrm{CH}), 128.4(\mathrm{Ph}), 127.9(\mathrm{Ph}), 127.8(\mathrm{Ph}), 127.3(=\mathrm{CH}), 72.6$ and $72.5(\mathrm{COH}), 66.7$ and 66.4 $\left(\mathrm{CH}_{2} \mathrm{Ph}\right), 57.3$ and $56.8(\mathrm{NCH}), 46.8$ and $46.4\left(\mathrm{NCH}_{2}\right), 39.3\left(\mathrm{CH}_{2} \mathrm{CH}=\mathrm{CH}\right), 37.2$ and $36.5\left(\mathrm{CH}_{2}\right), 30.0$ and $29.4\left(\mathrm{CH}_{2}\right), 23.6$ and $22.8\left(\mathrm{CH}_{2}\right), 18.6\left(\mathrm{CH}_{2}\right), 14.0(\mathrm{Me})$. Spectroscopic data consistent with that reported in the literature. ${ }^{14}$ 


\section{(S)-Benzyl 2-((E)-4-oxohept-2-enyl)pyrrolidine-1-carboxylate 19}

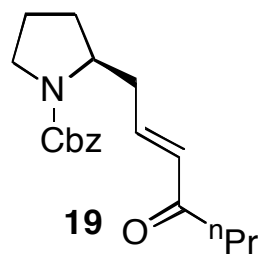

Dess-Martin periodinane $(422 \mathrm{mg}, 1.00 \mathrm{mmol})$ was added in one portion to a stirred solution of alcohol 18 (142 mg, $0.45 \mathrm{mmol})$ in $\mathrm{CH}_{2} \mathrm{Cl}_{2}(4 \mathrm{~mL})$ at $\mathrm{rt}$ under Ar. The resulting mixture was stirred at $\mathrm{rt}$ for $1 \mathrm{~h}$. Then, $\mathrm{CH}_{2} \mathrm{Cl}_{2}(7 \mathrm{~mL})$ and a solution of $\mathrm{Na}_{2} \mathrm{~S}_{2} \mathrm{O}_{3}(1.0 \mathrm{~g})$ in $5 \% \mathrm{NaHCO}_{3(\mathrm{aq})}(10 \mathrm{~mL})$ were added. The resulting mixture was stirred at $\mathrm{rt}$ for $15 \mathrm{~min}$. The two layers were separated and the aqueous layer was extracted with $\mathrm{CH}_{2} \mathrm{Cl}_{2}(3 \times 10 \mathrm{~mL})$. The combined organic extracts were dried $\left(\mathrm{Na}_{2} \mathrm{SO}_{4}\right)$ and evaporated under reduced pressure to give the crude product as a yellow oil. Purification by flash column chromatography on silica with petrol-EtOAc (85:15) as eluent gave ketone 19 (111 $\mathrm{mg}, 72 \%)$ as a colourless oil, $[\alpha]^{24}-74.6\left(c 0.33\right.$ in $\left.\mathrm{CHCl}_{3}\right) ; R_{\mathrm{F}}(5: 1$ petrol-EtOAc) 0.36; IR (neat) $2962(\mathrm{CH}), 1697$ $(\mathrm{C}=\mathrm{O}), 1627(\mathrm{C}=\mathrm{O}), 1411(\mathrm{C}=\mathrm{C}) \mathrm{cm}^{-1} ;{ }^{1} \mathrm{H} \mathrm{NMR}\left(400 \mathrm{MHz}, \mathrm{CDCl}_{3}\right)$ approx 2:3 mixture of rotamers $\delta$ 7.46-7.23 (m, 5H, Ph), 6.86-6.84 (m, 1H, CH=CH(CO)), 6.12 (d, J = 16.0 Hz, 0.6H, CH=CH(CO)), 6.05 $(\mathrm{d}, J=16.0 \mathrm{~Hz}, 0.4 \mathrm{H} \mathrm{CH}=\mathrm{CH}(\mathrm{CO})), 5.15\left(\right.$ br s, $\left.0.8 \mathrm{H}, \mathrm{CH}_{2} \mathrm{Ph}\right), 5.13$ (br s, 1.2H, $\left.\mathrm{CH}_{2} \mathrm{Ph}\right), 4.08-3.94$ (m, $1 \mathrm{H}, \mathrm{NCH}), 3.55-3.34\left(\mathrm{~m}, 2 \mathrm{H}, \mathrm{NCH}_{2}\right), 2.79-2.67\left(\mathrm{~m}, 0.6 \mathrm{H}, \mathrm{CH}_{\mathrm{A}} \mathrm{H}_{\mathrm{B}} \mathrm{CH}=\mathrm{CH}\right), 2.61-2.52(\mathrm{~m}, 0.4 \mathrm{H}$, $\left.\mathrm{CH}_{\mathrm{A}} \mathrm{H}_{\mathrm{B}} \mathrm{CH}=\mathrm{CH}\right), 2.50\left(\mathrm{t}, J=7.5 \mathrm{~Hz}, 1.2 \mathrm{H}, \mathrm{C}(\mathrm{O}) \mathrm{CH}_{2}\right), 2.45\left(\mathrm{t}, J=7.0 \mathrm{~Hz}, 0.8 \mathrm{H}, \mathrm{C}\left(\mathrm{O}_{)} \mathrm{CH}_{2}\right), 2.41-2.26(\mathrm{~m}\right.$, $\left.1 \mathrm{H}, \mathrm{CH}_{\mathrm{A}} \mathrm{H}_{\mathrm{B}} \mathrm{CH}=\mathrm{CH}\right)$ 2.04-1.77 (m, 3H, $\mathrm{CH}_{2}$ and $\left.\mathrm{CH}\right), 1.75\left(\mathrm{~m}, 3 \mathrm{H}, \mathrm{CH}\right.$ and $\left.\mathrm{CH}_{2}\right), 0.93(\mathrm{t}, J=7.5 \mathrm{~Hz}$, $3 \mathrm{H}, \mathrm{Me}) ;{ }^{13} \mathrm{C}$ NMR $\left(100.6 \mathrm{MHz}, \mathrm{CDCl}_{3}\right)$ approx 2:3 mixture of rotamers $\delta 200.3(\mathrm{C}=\mathrm{O}), 154.8(\mathrm{C}=\mathrm{O})$, 143.0 and $142.5(\mathrm{CH}=\mathrm{CH}(\mathrm{CO})), 136.9($ ipso $-\mathrm{Ph}), 132.4(\mathrm{CH}=\mathrm{CH}(\mathrm{CO})), 128.5(\mathrm{Ph}), 128.0(\mathrm{Ph}), 127.9$ $(\mathrm{Ph}), 127.8(\mathrm{Ph}), 66.9$ and $66.6\left(\mathrm{CH}_{2} \mathrm{Ph}\right), 56.7$ and $56.1(\mathrm{NCH}), 46.8$ and $46.5\left(\mathrm{NCH}_{2}\right), 42.2$ and 41.9 $\left(\mathrm{C}(\mathrm{O}) \mathrm{CH}_{2}\right), 37.6$ and $36.8\left(\mathrm{CH}_{2} \mathrm{CH}=\mathrm{CH}\right), 30.4$ and $29.6\left(\mathrm{NCHCH}_{2}\right), 23.6$ and $22.9\left(\mathrm{NCH}_{2} \mathrm{CH}_{2}\right), 17.6$ and $17.5\left(\mathrm{CH}_{2} \mathrm{Me}\right), 13.7(\mathrm{Me})$; MS (ESI) $m / z 338\left[(\mathrm{M}+\mathrm{Na})^{+}, 100\right], 316\left[(\mathrm{M}+\mathrm{H})^{+}, 33\right]$; HRMS $(\mathrm{ESI}) \mathrm{m} / z$ $[\mathrm{M}+\mathrm{Na}]^{+}$calcd for $\mathrm{C}_{19} \mathrm{H}_{25} \mathrm{NO}_{3}, 338.1732$; found 338.1727. 


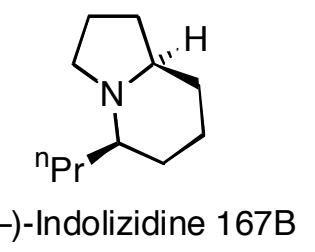

A suspension of $10 \%(\mathrm{w} / \mathrm{w}) \mathrm{Pd} / \mathrm{C}(40 \mathrm{mg}, 0.038 \mathrm{mmol})$ in $\mathrm{MeOH}(2 \mathrm{~mL})$ was added to stirred solution of ketone 19 (60 mg, $0.19 \mathrm{mmol})$ in $\mathrm{MeOH}(1 \mathrm{~mL})$ at $\mathrm{rt}$ under $\mathrm{N}_{2}$. The flask was evacuated and back-filled with $\mathrm{N}_{2}$ three times. Then, the flask was evacuated and back-filled with $\mathrm{H}_{2}$. The resulting mixture was stirred at $\mathrm{rt}$ under $\mathrm{H}_{2}$ for $16 \mathrm{~h}$. Then, $\mathrm{CH}_{2} \mathrm{Cl}_{2}(20 \mathrm{~mL})$ was added and the solids were removed by filtration through a pad of Celite ${ }^{\circledR}$ and washed with $\mathrm{CH}_{2} \mathrm{Cl}_{2}(2 \times 5 \mathrm{~mL})$. The filtrate was evaporated under reduced pressure to give the crude product as a yellow/browm oil. Purification by flash column chromatography on a pad of $\mathrm{Et}_{3} \mathrm{~N}$-deactivated silica with petrol-EtOAc $(1: 1 \rightarrow 0: 1)$ as eluent gave $(-)$-indolizidine $167 \mathrm{~B}(26$ mg, 81\%) as a yellow oil, [ $\alpha]_{\mathrm{D}}^{24}-89.5\left(c 0.2\right.$ in $\left.\mathrm{CH}_{2} \mathrm{Cl}_{2}\right)$ (lit., ${ }^{15}[\alpha]_{\mathrm{D}}^{24}-115\left(c 1.17\right.$ in $\left.\mathrm{CH}_{2} \mathrm{Cl}_{2}\right)$ for (-)indolizidine $167 \mathrm{~B}$ of $\geq 99: 1 \mathrm{er}) ; R_{\mathrm{F}}\left(1: 1\right.$ petrol-EtOAc) on $\mathrm{Et}_{3} \mathrm{~N}$ deactivated silica $0.2 ;{ }^{1} \mathrm{H} \mathrm{NMR}(400 \mathrm{MHz}$, $\left.\mathrm{CDCl}_{3}\right) \delta 3.28(\operatorname{td} J=9.0,2.0 \mathrm{~Hz}, 1 \mathrm{H}, \mathrm{NCH}), 2.06-1.54\left(\mathrm{~m}, 10 \mathrm{H}, 4 \times \mathrm{CH}_{2}, \mathrm{NCH}\right.$ and $\left.\mathrm{CH}\right), 1.54-1.67$ (m, 7H, $\mathrm{CH}$ and $\left.3 \mathrm{x} \mathrm{CH}_{2}\right), 0.90(\mathrm{t}, J=7.0 \mathrm{~Hz}, 3 \mathrm{H}, \mathrm{Me}) ;{ }^{13} \mathrm{C} \mathrm{NMR}\left(100.6 \mathrm{MHz}, \mathrm{CDCl}_{3}\right) \delta 65.2(\mathrm{NCH}), 63.7$ (NCH), $51.3\left(\mathrm{NCH}_{2}\right), 36.5\left(\mathrm{CH}_{2}\right), 30.5\left(\mathrm{CH}_{2}\right), 30.4\left(\mathrm{CH}_{2}\right), 30.3\left(\mathrm{CH}_{2}\right), 20.3\left(\mathrm{CH}_{2}\right), 19.1\left(\mathrm{CH}_{2}\right), 14.4$ (Me). Spectroscopic data is consistent with that reported in the literature. ${ }^{15}$

\section{(R)-tert-Butyl 2-phenylpyrrolidine-1-carboxylate 20}

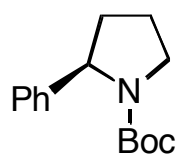

20

$s$-BuLi (1.32 mL of a $1.30 \mathrm{M}$ solution in cyclohexane, $1.75 \mathrm{mmol})$ was added dropwise to a stirred solution of $N$-Boc pyrrolidine $7(307 \mu \mathrm{L}, 1.75 \mathrm{mmol})$ and (-)-sparteine (402 $\mu \mathrm{L}, 1.75 \mathrm{mmol})$ in $\mathrm{Et}_{2} \mathrm{O}(3.5$ $\mathrm{mL})$ at $-78{ }^{\circ} \mathrm{C}$ under Ar. The resulting solution was stirred at $-78{ }^{\circ} \mathrm{C}$ for $3 \mathrm{~h}$. Then, $\mathrm{ZnCl}_{2}(1.04 \mathrm{~mL}$ of a 1.0 $\mathrm{M}$ solution in $\mathrm{Et}_{2} \mathrm{O}, 1.04 \mathrm{mmol}$ ) was added dropwise and the resulting solution was stirred at $-78{ }^{\circ} \mathrm{C}$ 
for $30 \mathrm{~min}$. Then, the solution was allowed to warm to rt over $15 \mathrm{~min}$, followed by stirring at rt for $20 \mathrm{~min}$. Then, bromobenzene $(153 \mu \mathrm{L}, 1.46 \mathrm{mmol})$ and a mixture of ${ }^{t} \mathrm{Bu}_{3} \mathrm{PHBF}_{4}(25 \mathrm{mg}, 0.09 \mathrm{mmol})$ and $\mathrm{Pd}(\mathrm{OAc})_{2}(16 \mathrm{mg}, 0.07 \mathrm{mmol})$ were added. The resulting mixture was stirred at $\mathrm{rt}$ for $16 \mathrm{~h}$. $\mathrm{NH}_{4} \mathrm{OH}_{(\mathrm{aq})}$ $(150 \mu \mathrm{L})$ was added and the mixture stirred at $\mathrm{rt}$ for $1 \mathrm{~h}$. The solids were removed by filtration through a pad of Celite ${ }^{\circledR}$ and washed with $\mathrm{Et}_{2} \mathrm{O}(20 \mathrm{~mL})$. The filtrate was washed with $1 \mathrm{M} \mathrm{HCl}_{(\mathrm{aq})}(15 \mathrm{~mL})$ and water ( $2 \times 15 \mathrm{~mL})$, dried $\left(\mathrm{MgSO}_{4}\right)$ and evaporated under reduced pressure to give the crude product as a yellow oil. Purification by flash column chromatography on silica with $\mathrm{CH}_{2} \mathrm{Cl}_{2}$ as eluent gave pyrrolidine $(R)$-20 (307 mg, 81\%, 95:5 er by chiral HPLC) as a colourless oil that solidifies of standing, mp 58-60 ${ }^{\circ} \mathrm{C}$ (lit., ${ }^{16}$ 61.9-62.7 $\left.{ }^{\circ} \mathrm{C}\right) ;[\alpha]_{\mathrm{D}}^{24}+83.2\left(c 0.7\right.$ in acetone) (lit., ${ }^{16}[\alpha]_{\mathrm{D}}^{24}+85.3\left(c 0.019\right.$ in acetone)); $R_{\mathrm{F}}\left(\mathrm{CH}_{2} \mathrm{Cl}_{2}\right) 0.25$; ${ }^{1} \mathrm{H}$ NMR $\left(400 \mathrm{MHz}, \mathrm{CDCl}_{3}\right.$ ) rotamers present $\delta$ 7.33-7.26 (m, 2H, Ph), 7.25-7.13 (m, 3H, Ph), 5.03-4.90 (br m, 0.33H, NCHPh), 4.83-4.70 (m, 0.66H, NCHPh), 3.72-3.45 (m, 2H, $\mathrm{NCH}_{2}$ ), 2.42-2.20 (br m, 1H, $\left.\mathrm{CH}_{\mathrm{A}} \mathrm{H}_{\mathrm{B}}\right), 1.99-1.77\left(\mathrm{~m}, 3 \mathrm{H}, \mathrm{CH}_{\mathrm{A}} H_{\mathrm{B}}\right.$ and $\left.\mathrm{CH}_{2}\right), 1.46\left(\mathrm{~s}, 3 \mathrm{H}, \mathrm{CMe}_{3}\right), 1.18\left(\mathrm{~s}, 6 \mathrm{H}, \mathrm{CMe}_{3}\right) ;{ }^{13} \mathrm{C}$ NMR (100.6 $\left.\mathrm{MHz}, \mathrm{CDCl}_{3}\right)$ rotamers present $\delta 154.5(\mathrm{C}=\mathrm{O}), 145.1$ (ipso-Ph), $128.1(2 \times \mathrm{Ph}), 125.5(\mathrm{Ph}), 79.1\left(C \mathrm{Me}_{3}\right)$, 61.3 and 60.6 (CHPh), 47.0 $\left(\mathrm{NCH}_{2}\right), 36.0\left(\mathrm{CH}_{2}\right), 28.5$ and $28.1\left(\mathrm{CMe}_{3}\right), 23.4\left(\mathrm{CH}_{2}\right), 23.39\left(\mathrm{CH}_{2}\right) ; \mathrm{Chiral}^{2}$ HPLC: Chiralpak AD, 99:1 hexane/i-PrOH, $0.5 \mathrm{mLmin}^{-1}, 9.40 \mathrm{~min}[(R)-20]$ and $11.84 \min [(S)-20] .{ }^{16}$

\section{(2S,5R)-Methyl 5-phenylpyrrolidine-2-carboxylate cis-22 and methyl 2-phenylpyrrolidine-2-}

\section{carboxylate 23}

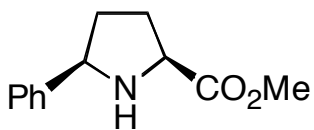

cis-22

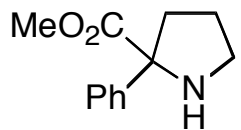

23

$s$-BuLi (1.28 mL of a $1.20 \mathrm{M}$ solution in cyclohexane, $1.53 \mathrm{mmol})$ was added dropwise to a stirred solution of pyrrolidine $(R)-\mathbf{2 0}(250 \mathrm{mg}, 0.96 \mathrm{mmol})$ and diamine $(S, S)-\mathbf{4}(475 \mathrm{mg}, 1.53 \mathrm{mmol})$ in $\mathrm{Et}_{2} \mathrm{O}(2.5$ $\mathrm{mL}$ ) at $-78{ }^{\circ} \mathrm{C}$ under Ar. The resulting solution was stirred at $-78{ }^{\circ} \mathrm{C}$ for $6 \mathrm{~h}$. Then, a stream of $\mathrm{CO}_{2}$ was bubbled into the solution for $1 \mathrm{~h}$ and the solution was allowed to warm to $\mathrm{rt}$ and stirred at $\mathrm{rt}$ for $16 \mathrm{~h}$. $1 \mathrm{M}$ $\mathrm{HCl}_{(\mathrm{aq})}(10 \mathrm{~mL})$ and EtOAc $(10 \mathrm{~mL})$ were added and the two layers were separated. The aqueous layer was extracted with EtOAc $(5 \times 10 \mathrm{~mL})$ and the combined organic extracts were dried $\left(\mathrm{Na}_{2} \mathrm{SO}_{4}\right)$ and evaporated 
under pressure to give the crude acids as a pale yellow oil. To a stirred solution of the crude acid in 1:1 $\mathrm{MeOH}$-toluene $(14 \mathrm{~mL})$ at $0{ }^{\circ} \mathrm{C}$ under $\mathrm{Ar}$ trimethylsilyldiazomethane $(534 \mu \mathrm{L}$ of a $2 \mathrm{M}$ solution in hexanes, $1.07 \mathrm{mmol}$ ) was added dropwise. The resulting solution was stirred at $\mathrm{rt}$ for $1 \mathrm{~h}$. Acetic acid (11 $\mu \mathrm{L}, 0.2 \mathrm{mmol}$ ) was added dropwise and the solvent was evaporated under reduced pressure to give the crude methyl esters. To a stirred solution of the crude methyl esters in $\mathrm{CH}_{2} \mathrm{Cl}_{2}(2.5 \mathrm{~mL})$ at $0{ }^{\circ} \mathrm{C}$ under $\mathrm{Ar}$ TFA (250 $\mu \mathrm{L}, 3.25 \mathrm{mmol})$ was added dropwise. The resulting solution was stirred at rt for $3 \mathrm{~h}$. $\mathrm{CH}_{2} \mathrm{Cl}_{2}$ $(2.5 \mathrm{~mL})$ and $1 \mathrm{M} \mathrm{NaOH}_{(\mathrm{aq})}(5 \mathrm{~mL})$ were added and the resulting layers were separated. The aqueous layer was extracted with $\mathrm{CH}_{2} \mathrm{Cl}_{2}(3 \times 10 \mathrm{~mL})$ and the combined organic extracts were dried $\left(\mathrm{MgSO}_{4}\right)$ and evaporated under reduced pressure to give the crude product as a yellow oil. Purification by flash column chromatography on silica with petrol-EtOAc (7:3) as eluent gave cis-pyrrolidine cis-22 (51 mg, 33\% over 3 steps, $\geq 99: 1$ er by chiral HPLC) as a pale yellow oil, $[\alpha]_{\mathrm{D}}^{24}+14.7\left(c 0.45\right.$ in $\left.\mathrm{CH}_{2} \mathrm{Cl}_{2}\right)\left(\right.$ lit., ${ }^{17}[\alpha]^{24}{ }_{\mathrm{D}}+15.3$ (c 1.22 in $\mathrm{CH}_{2} \mathrm{Cl}_{2}$ ) for $\left.(2 S, 5 R)-22\right) ; R_{\mathrm{F}}\left(7: 3\right.$ petrol-EtOAc) $0.15 ;{ }^{1} \mathrm{H} \mathrm{NMR}\left(400 \mathrm{MHz}, \mathrm{CDCl}_{3}\right) \delta 7.45(\mathrm{~d}, J$ $=7.5 \mathrm{~Hz}, 2 \mathrm{H}, o-\mathrm{Ph}), 7.36(\mathrm{t}, J=7.5 \mathrm{~Hz}, 2 \mathrm{H}, m-\mathrm{Ph}), 7.30(\mathrm{~d}, J=7.5 \mathrm{~Hz}, 1 \mathrm{H} p-\mathrm{Ph}), 4.31(\mathrm{dd}, J=10.0,6.0$ $\mathrm{Hz}, 1 \mathrm{H}, \mathrm{NCH}), 4.06(\mathrm{dd}, J=9.0,4.5 \mathrm{~Hz}, 1 \mathrm{H}, \mathrm{NCH}), 3.80$ (s, 3H, Me), 2.39-2.35 (m, 3H, $\mathrm{CH}_{2}$ and $\left.\mathrm{CH}_{\mathrm{A}} \mathrm{H}_{\mathrm{B}}\right), 1.84-1.73\left(\mathrm{~m}, 1 \mathrm{H}, \mathrm{CH}_{\mathrm{A}} H_{\mathrm{B}}\right) ;{ }^{13} \mathrm{C} \mathrm{NMR}\left(100.6 \mathrm{MHz}, \mathrm{CDCl}_{3}\right) \delta 175.5(\mathrm{C}=\mathrm{O}), 143.1$ (ipso-Ph), $128.5(\mathrm{Ph}), 127.3(\mathrm{Ph}), 126.7(\mathrm{Ph}), 63.5(\mathrm{NCH}), 60.0(\mathrm{NCH}), 52.2(\mathrm{Me}), 34.1\left(\mathrm{CH}_{2}\right), 30.5\left(\mathrm{CH}_{2}\right)$. Chiral HPLC: Chiralpak AD 95:5 Hexane/i-PrOH, $0.5 \mathrm{mLmin}^{-1}, 22.71 \min [(2 R, 5 S)-22], 26.48 \min [(2 S, 5 R)-22]$ and amine $23(18 \mathrm{mg}, 22 \%$ over 3 steps $)$ as a pale yellow oil, $[\alpha]_{\mathrm{D}}^{24}-7.1\left(c 0.9\right.$ in $\left.\mathrm{CHCl}_{3}\right) ; R_{\mathrm{F}}(7: 3$ petrolEtOAc) 0.16; IR (neat) $2953(\mathrm{CH}), 2926(\mathrm{CH}), 2855(\mathrm{CH}), 1730(\mathrm{C}=\mathrm{O}) \mathrm{cm}^{-1} ;{ }^{1} \mathrm{H}$ NMR (400 MHz, $\left.\mathrm{CDCl}_{3}\right) \delta 7.45-7.50(\mathrm{~m}, 2 \mathrm{H}, o-\mathrm{Ph}), 7.33(\mathrm{t}, J=7.5 \mathrm{~Hz}, 2 \mathrm{H}, m-\mathrm{Ph}), 7.24(\mathrm{t}, J=7.5 \mathrm{~Hz}, 1 \mathrm{H}, p-\mathrm{Ph}), 3.69(\mathrm{~s}$, 3H, OMe), 3.16-3.06 (m, 2H, $\left.\mathrm{NCH}_{2}\right), 2.76\left(\mathrm{ddd}, J=12.5,8.0,5.0 \mathrm{~Hz}, 1 \mathrm{H}, \mathrm{NC}(\mathrm{Ph}) \mathrm{CH}_{\mathrm{A}} \mathrm{H}_{\mathrm{B}}\right), 2.59-1.97$ (br m, 1H, NH), 2.09 (dt, $\left.J=12.5,8.5 \mathrm{~Hz}, 1 \mathrm{H}, \mathrm{NC}(\mathrm{Ph}) \mathrm{CH}_{\mathrm{A}} H_{\mathrm{B}}\right), 1.95-1.76\left(\mathrm{~m}, 2 \mathrm{H}, \mathrm{CH}_{2}\right) ;{ }^{13} \mathrm{C} \mathrm{NMR}(100.6$ $\left.\mathrm{MHz}, \mathrm{CDCl}_{3}\right)$ \& $176.0(\mathrm{C}=\mathrm{O}), 142.6$ (ipso-Ph), $128.2(\mathrm{Ph}), 127.2(\mathrm{Ph}), 126.0(\mathrm{Ph}), 72.2(\mathrm{NCPh}), 52.7$ $(\mathrm{OMe}), 45.7\left(\mathrm{NCH}_{2}\right), 36.6\left(\mathrm{CH}_{2}\right), 24.5\left(\mathrm{CH}_{2}\right) ; \mathrm{MS}(\mathrm{ESI}) \mathrm{m} / z 228\left[(\mathrm{M}+\mathrm{Na})^{+}, 5\right], 206\left[(\mathrm{M}+\mathrm{H})^{+}, 20\right], 146$ $\left[\left(\mathrm{M}-\mathrm{CO}_{2} \mathrm{Me}\right)^{+} 100\right]$; HRMS (ESI) $m / z[\mathrm{M}+\mathrm{H}]^{+}$calcd for $\mathrm{C}_{12} \mathrm{H}_{15} \mathrm{NO}_{2}, 206.1181$; found 205.1176.

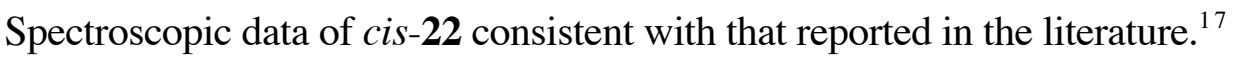




\section{2-carboxylate 23}

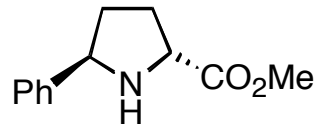

trans-24

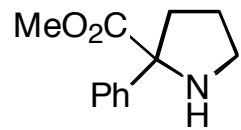

23

$s$-BuLi $(1.50 \mathrm{~mL}$ of a $1.20 \mathrm{M}$ solution in cyclohexane, $1.80 \mathrm{mmol})$ was added dropwise to a stirred solution of pyrrolidine $(R)-\mathbf{2 0}(294 \mathrm{mg}, 1.13 \mathrm{mmol})$ and (-)-sparteine $(413 \mu \mathrm{L}, 1.80 \mathrm{mmol})$ in $\mathrm{Et}_{2} \mathrm{O}(2.5$ $\mathrm{mL}$ ) at $-78{ }^{\circ} \mathrm{C}$ under Ar. The resulting solution was stirred at $-78{ }^{\circ} \mathrm{C}$ for $6 \mathrm{~h}$. Then, a stream of $\mathrm{CO}_{2}$ was bubbled into the solution for $1 \mathrm{~h}$ and the solution was allowed to warm to $\mathrm{rt}$ and stirred at $\mathrm{rt}$ for $16 \mathrm{~h}$. $1 \mathrm{M}$ $\mathrm{HCl}_{(\mathrm{aq})}(10 \mathrm{~mL})$ and EtOAc $(10 \mathrm{~mL})$ were added and the two layers were separated. The aqueous layer was extracted with EtOAc $(5 \times 10 \mathrm{~mL})$ and the combined organic extracts were dried $\left(\mathrm{Na}_{2} \mathrm{SO}_{4}\right)$ and evaporated under pressure to give the crude acids as a pale yellow oil. To a stirred soluition of the crude acids 1:1 $\mathrm{MeOH}$-toluene $(7 \mathrm{~mL})$ at $0{ }^{\circ} \mathrm{C}$ under $\mathrm{Ar}$, trimethylsilyldiazomethane $(713 \mu \mathrm{L}$ of a $2 \mathrm{M}$ solution in hexanes, $1.42 \mathrm{mmol}$ ) was added dropwise. The resulting solution was stirred at $\mathrm{rt}$ for $1 \mathrm{~h}$. Acetic acid (13 $\mu \mathrm{L}, 0.23$ mmol) was added dropwise and the solvent was evaporated under reduced pressure to give the crude methyl esters. To a stirred solution of the crude methyl esters in $\mathrm{CH}_{2} \mathrm{Cl}_{2}(3 \mathrm{~mL})$ at $0{ }^{\circ} \mathrm{C}$ under $\mathrm{Ar}$, TFA (300 $\mu \mathrm{L}, 3.89 \mathrm{mmol}$ ) was added dropwise. The resulting solution was stirred at $\mathrm{rt}$ for $2 \mathrm{~h} . \mathrm{CH}_{2} \mathrm{Cl}_{2}(5 \mathrm{~mL})$ and $1 \mathrm{M} \mathrm{NaOH}_{(\mathrm{aq})}(5 \mathrm{~mL})$ were added and the two layers were separated. The aqueous layer was extracted with $\mathrm{CH}_{2} \mathrm{Cl}_{2}(4 \times 5 \mathrm{~mL})$ and the combined organic extracts were dried $\left(\mathrm{MgSO}_{4}\right)$ and evaporated under reduced pressure to give the crude product as a yellow oil. Purification by flash column chromatography on silica with petrol-EtOAc (7:3) as eluent gave trans-pyrrolidine trans-24 (67 mg, 27\% over 3 steps) as a pale yellow oil, $[\alpha]^{24}+84.8$ (c 0.7 in $\mathrm{CH}_{2} \mathrm{Cl}_{2}$ ) (lit., ${ }^{18}[\alpha]_{\mathrm{D}}^{24}+82.0$ (c 1.00 in $\mathrm{CH}_{2} \mathrm{Cl}_{2}$ ) for $\left.(2 R, 5 R)-24\right)$; $R_{\mathrm{F}}\left(7: 3\right.$ petrol-EtOAc) $0.2 ;{ }^{1} \mathrm{H} \mathrm{NMR}\left(400 \mathrm{MHz}, \mathrm{CDCl}_{3}\right) \delta 7.41-7.36(\mathrm{~m}, 2 \mathrm{H}, o-\mathrm{Ph}), 7.33(\mathrm{t}, J=7.5 \mathrm{~Hz}, 2 \mathrm{H}$, $m-\mathrm{Ph}), 7.24(\mathrm{t}, J=7.5 \mathrm{~Hz}, 1 \mathrm{H} p-\mathrm{Ph}), 4.37(\mathrm{dd}, J=8.5,6.0 \mathrm{~Hz}, 1 \mathrm{H}, \mathrm{NCH}), 4.06(\mathrm{dd}, J=8.5,6.0 \mathrm{~Hz}, 1 \mathrm{H}$, $\mathrm{NCH}$ ), 3.77 (s, 3H, Me), 2.36 (dtd, $J=13.0,8.5,4.0 \mathrm{~Hz}, 1 \mathrm{H}, \mathrm{CH}), 2.21$ (ddddd, $J=12.0,8.0,6.5,4.0,0.5$ $\mathrm{Hz}, 1 \mathrm{H}, \mathrm{CH}), 2.00$ (dddd, $J=13.0,8.5,8.0,6.0 \mathrm{~Hz}, 1 \mathrm{H}, \mathrm{CH}), 1.75(\mathrm{dq}, J=12.0,8.5 \mathrm{~Hz}, 1 \mathrm{H}, \mathrm{CH}) ;{ }^{13} \mathrm{C}$ NMR (100.6 MHz, $\left.\mathrm{CDCl}_{3}\right) \delta 176.3(\mathrm{C}=\mathrm{O}), 144.3($ ipso-Ph), $128.3(\mathrm{Ph}), 126.8(\mathrm{Ph}), 126.4(\mathrm{Ph}), 61.7$ $(\mathrm{NCH}), 59.4(\mathrm{NCH}), 52.1(\mathrm{OMe}), 34.5\left(\mathrm{CH}_{2}\right), 29.7\left(\mathrm{CH}_{2}\right)$ and $23(44 \mathrm{mg}, 27 \%$ over 3 steps $)$ as a pale 
yellow oil, $[\alpha]^{24}{ }_{\mathrm{D}}-44.5\left(\mathrm{c} 0.05\right.$ in $\left.\mathrm{CHCl}_{3}\right)$. Spectroscopic data for trans-24 consistent with that reported in the literature. ${ }^{19}$ 


\section{Representative GC/HPLC data}

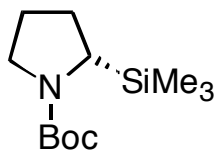

$(S)-8$

Data File C:\HPCHEM $\backslash \backslash$ DATA $\backslash G J G 1205 \backslash M M C A 0119 . D$

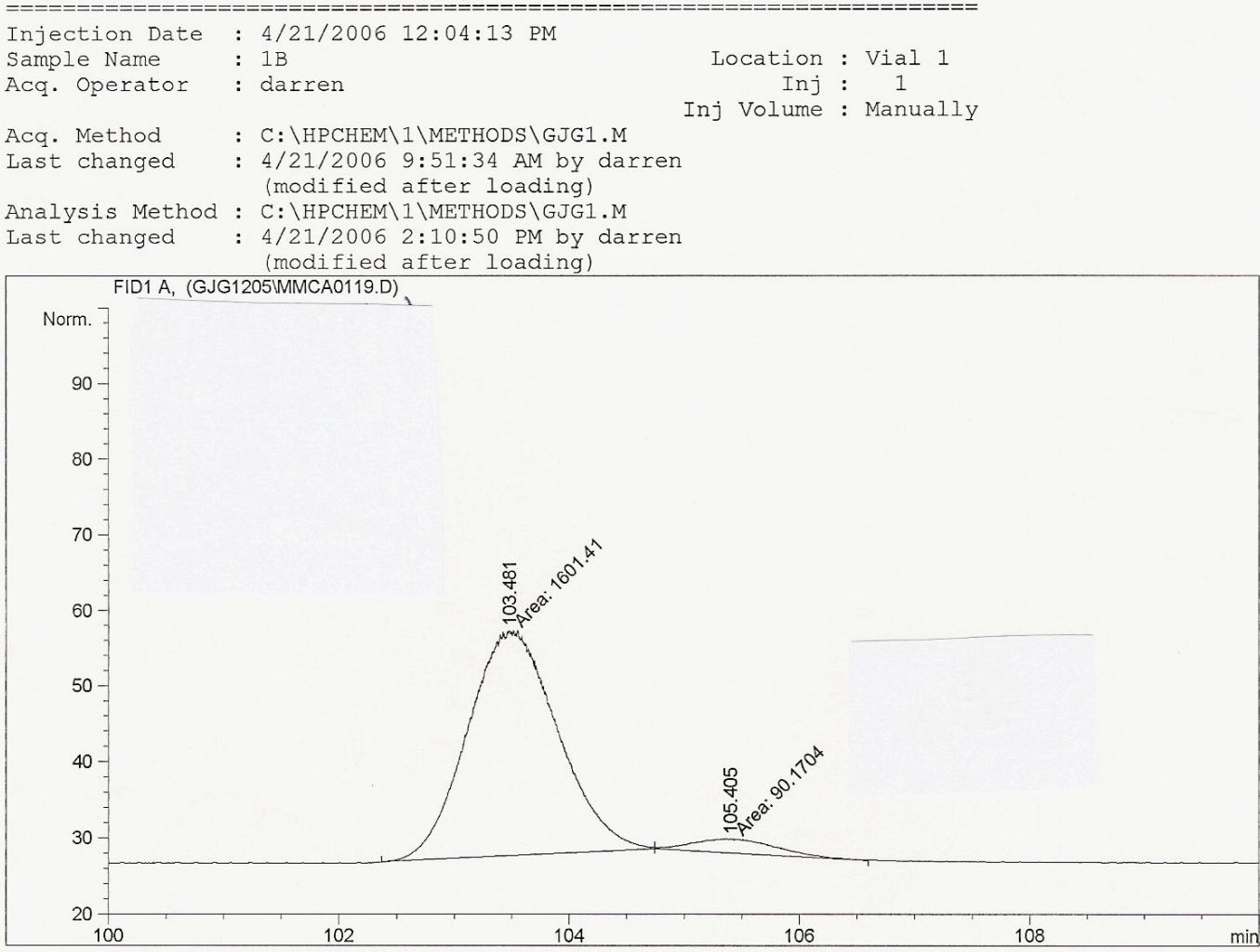

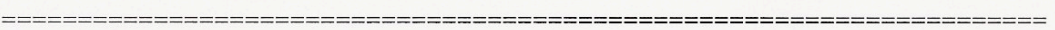

Area Percent Report

$\begin{array}{lcl} & & \\ \text { Sorted By } & : & \text { Signal } \\ \text { Multiplier } & : & 1.0000 \\ \text { Dilution } & : & 1.0000 \\ \text { Sample Amount } & : & 1.00000 \text { [ng/ul] (not used in calc.) }\end{array}$

Use Multiplier \& Dilution Factor with ISTDs

Signal 1: FID1 A,

\begin{tabular}{|c|c|c|c|c|c|c|}
\hline $\begin{array}{c}\text { Peak } \\
\#\end{array}$ & $\begin{array}{l}\text { RetTime } \\
\text { [min] }\end{array}$ & Type & $\begin{array}{l}\text { Width } \\
\text { [min] }\end{array}$ & $\begin{array}{r}\text { Area } \\
{\left[\mathrm{pA}^{\star} \mathrm{s}\right]}\end{array}$ & $\begin{array}{l}\text { Height } \\
\text { [pA] }\end{array}$ & $\begin{array}{c}\text { Area } \\
\text { 8 }\end{array}$ \\
\hline 1 & 2.496 & BV & 0.0441 & 146.20901 & 50.06079 & 0.01364 \\
\hline 2 & 2.626 & VV & 0.0238 & 175.93367 & 115.16186 & 0.01641 \\
\hline 3 & 2.706 & VB $S$ & 0.0862 & $1.07018 \mathrm{e} 6$ & 1.55609 e 5 & 99.81071 \\
\hline 4 & 3.426 & BV $\mathrm{X}$ & 0.0337 & 2.18733 & $9.94188 e^{-1}$ & 0.00020 \\
\hline 5 & 7.192 & $\mathrm{BP}$ & 0.0796 & 1.45502 & $2.84901 e-1$ & 0.00014 \\
\hline 6 & 69.304 & VV & 0.2796 & 8.35262 & $3.56197 e^{-1}$ & 0.00078 \\
\hline 7 & 69.444 & VB & 0.1623 & 3.89431 & $2.90738 e^{-1}$ & 0.00036 \\
\hline 8 & 103.481 & $\mathrm{MM}$ & 0.9034 & 1601.40881 & 29.54518 & 0.14936 \\
\hline 9 & 105.405 & $\mathrm{MM}$ & 0.8205 & 90.17042 & 1.83152 & 0.00841 \\
\hline ta & & & & $1.07220 \mathrm{e} 6$ & $1.55808 e 5$ & \\
\hline
\end{tabular}

Instrument 1 4/21/2006 2:17:38 PM darren 
<smiles>OCC(O)CCc1ccccc1</smiles>

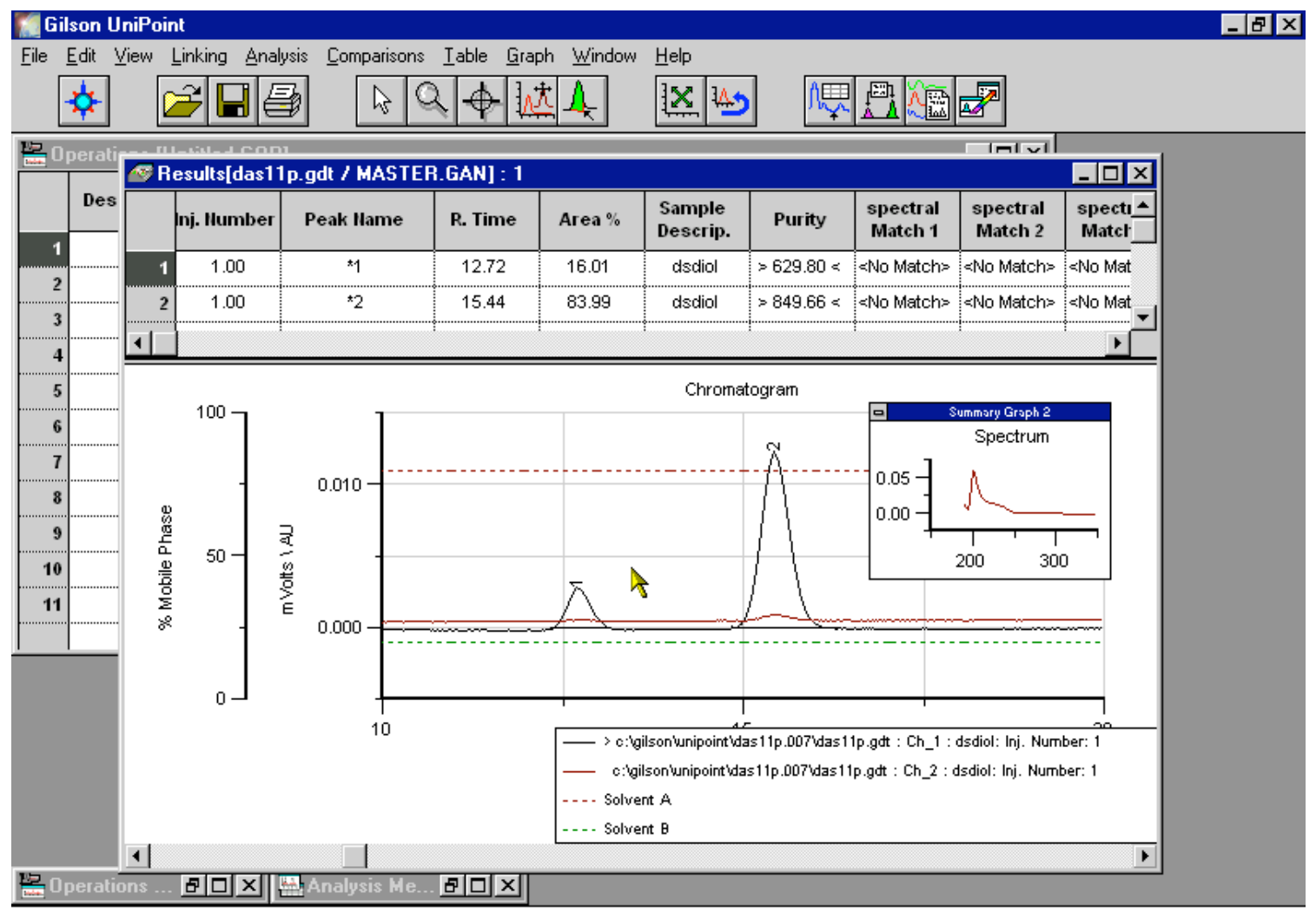




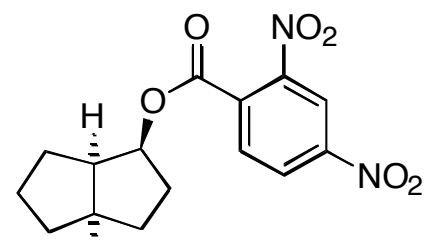

Ḧ

10/08/2006 16:38:59

Chromatogram Name: 59M-0000-556-001_opt_1

Vial Number: 9

Method Name: 59M-0000-556-001_opt

Injection Volume: $10.000 \mathrm{ul}$

Operator: John Burnett

Sample Name: 59M-0000-556-001

Column: AD-H

Mobile Phase- $30 \%$ MeOHIPAm

Flow: $5(\mathrm{ml} / \mathrm{min})$

Pressure: 100 (bar)

Temperature: 35 (C)

Wavelength: $220(\mathrm{~nm})$

Comments: $30 \% \mathrm{MeOH}(0.2 \%$ IPAm), AD-H

59M-0000-556-001_opt_1.DATA - Detector 1 Signal (UV)

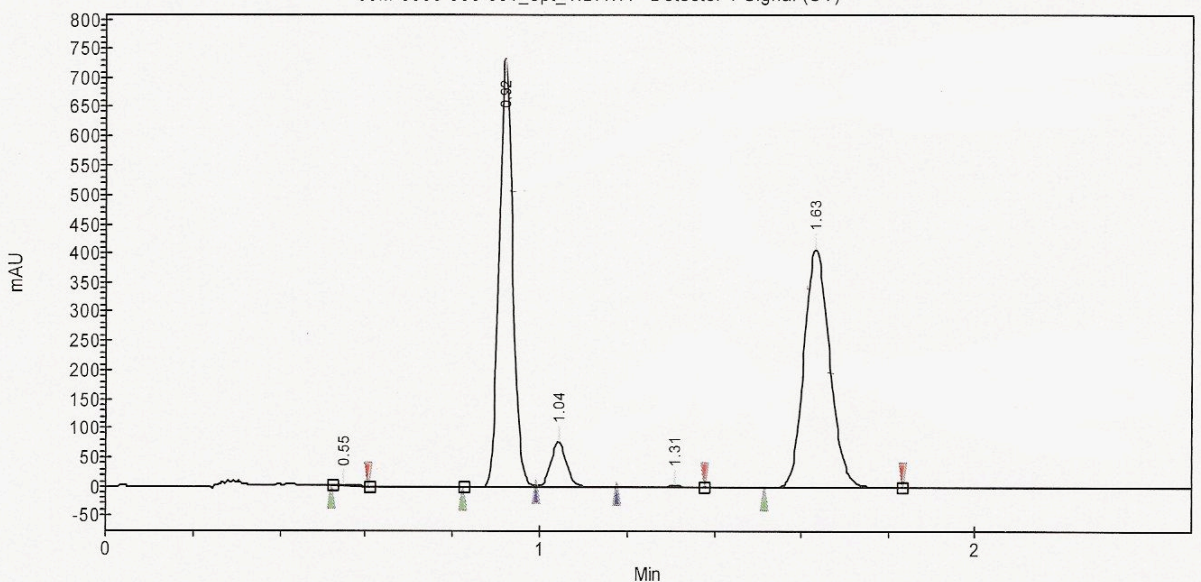

Min

\begin{tabular}{|c|r|r|r|r|r|}
\hline Index & Time & Width 10\% & Height & Area & Area \\
\hline & [Min] & {$[\mathrm{Min}]$} & {$[\mathrm{mAU}]$} & {$[\mathrm{mAU}$ min] } & {$[\%]$} \\
\hline 1 & 0.55 & 0.07 & 2.54 & 0.11 & 0.186 \\
\hline 2 & 0.92 & 0.06 & 733.55 & 26.92 & 46.134 \\
\hline 3 & 1.04 & 0.07 & 76.90 & 3.30 & 5.659 \\
\hline 4 & 1.31 & 0.12 & 2.59 & 0.16 & 0.275 \\
\hline 5 & 1.63 & 0.12 & 407.16 & 27.86 & 47.746 \\
\hline & & & & & \\
\hline Total & & & & 58.35 & 100.000 \\
\hline
\end{tabular}




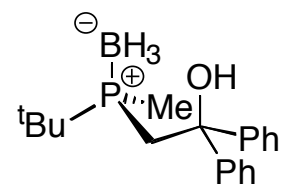

(R)-14

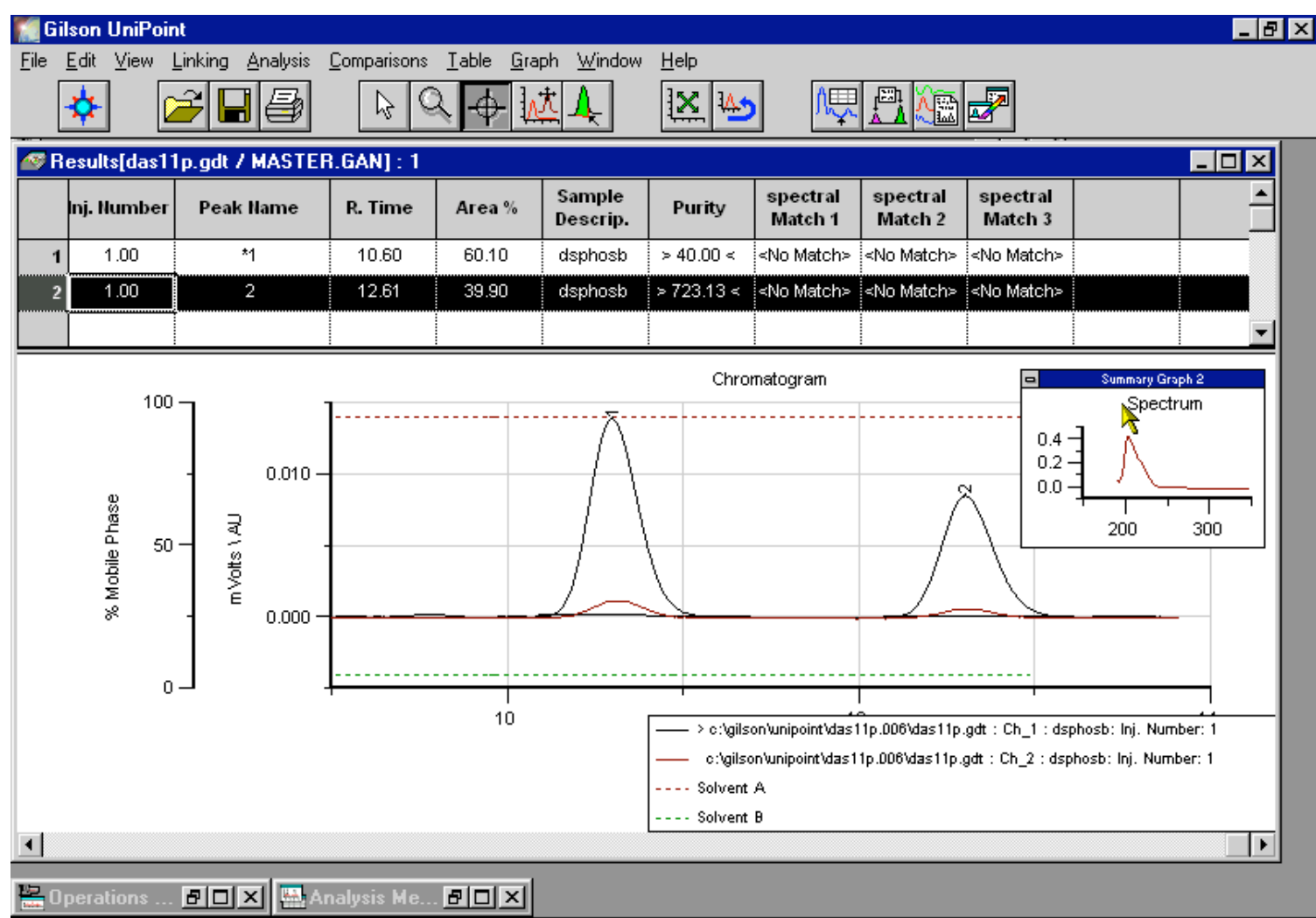




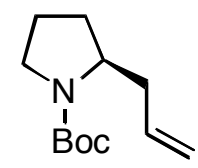

15

Data File C: $\backslash$ CHEM32\1\DATA DARREN $\backslash$ STXDALLYLPYTYROLIDINERUN1.D

Sample Name: DS8.83.Prun1
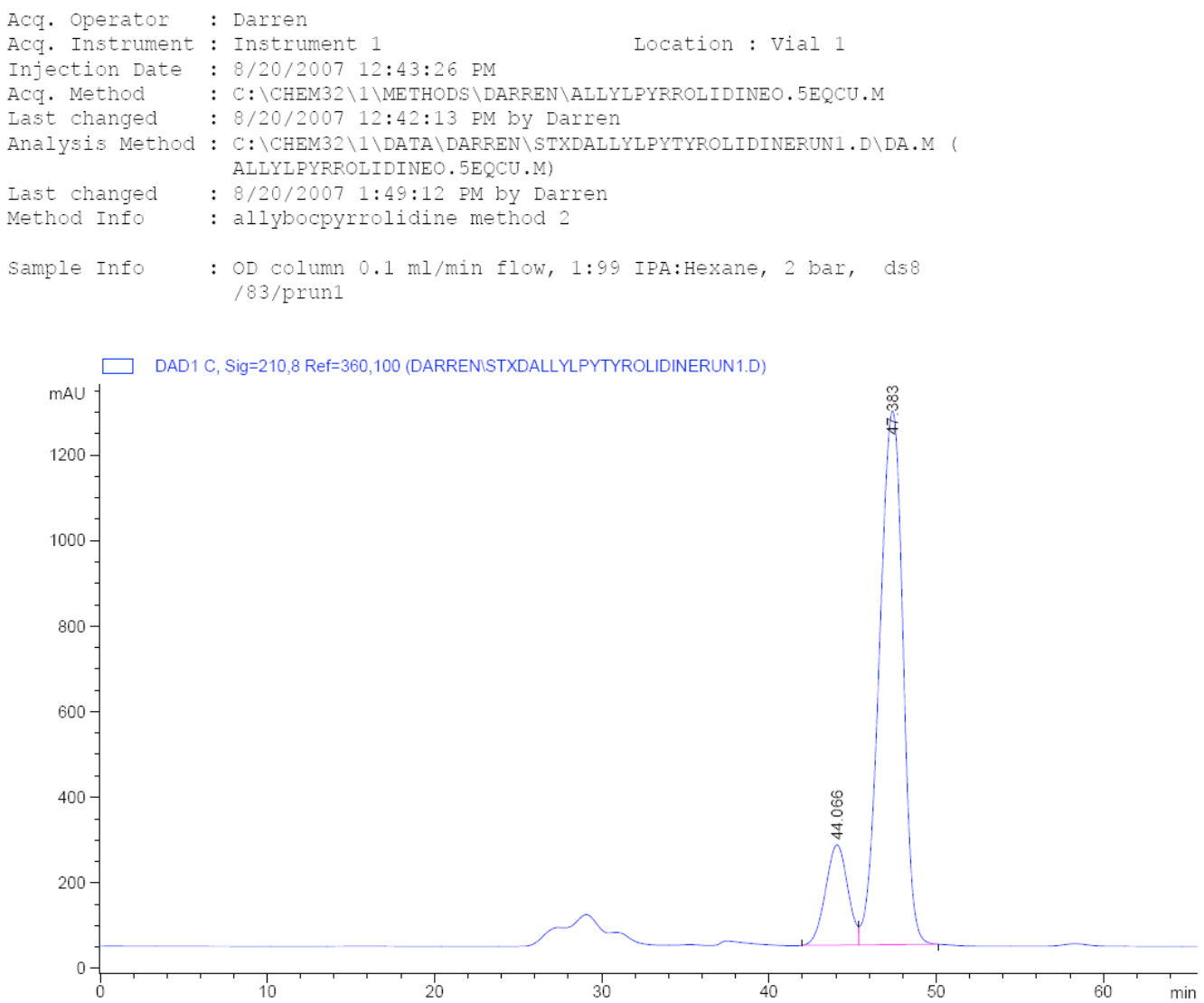

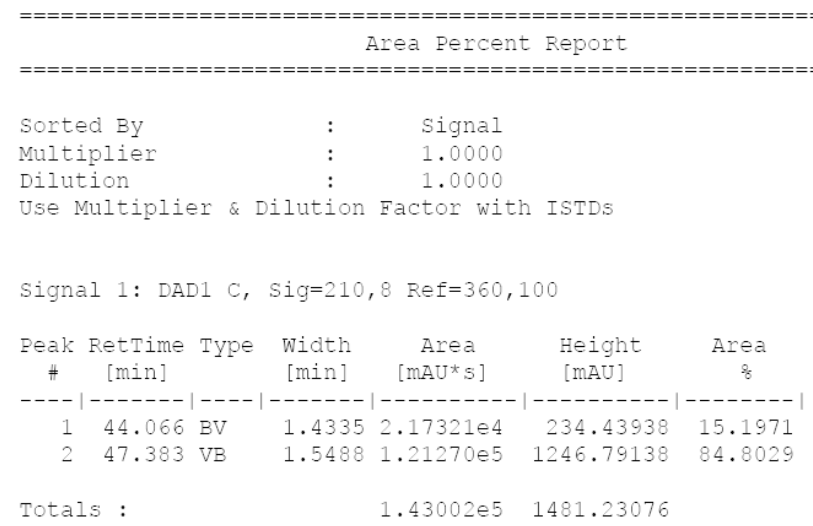

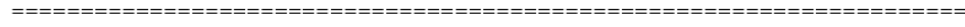


<smiles>O=C(OC(=O)N1CCCC1c1ccccc1)c1ccccc1</smiles>

20

Gilson UniPoint

- 回 $x$

File É dit View Linking Änalysis Comparisons Iable Graph Window Help
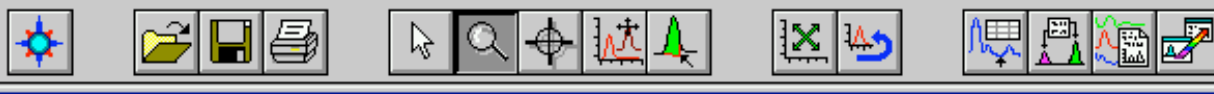

F Results[neg2.gdt / MASTER.GAN] : 1

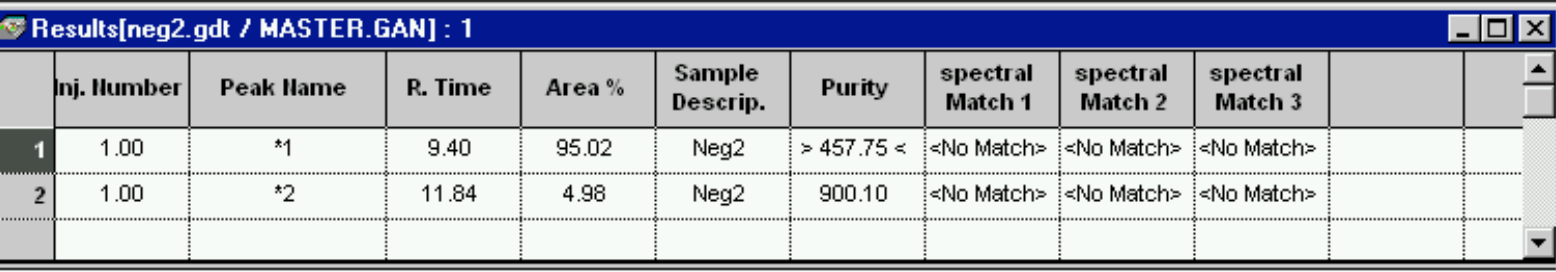

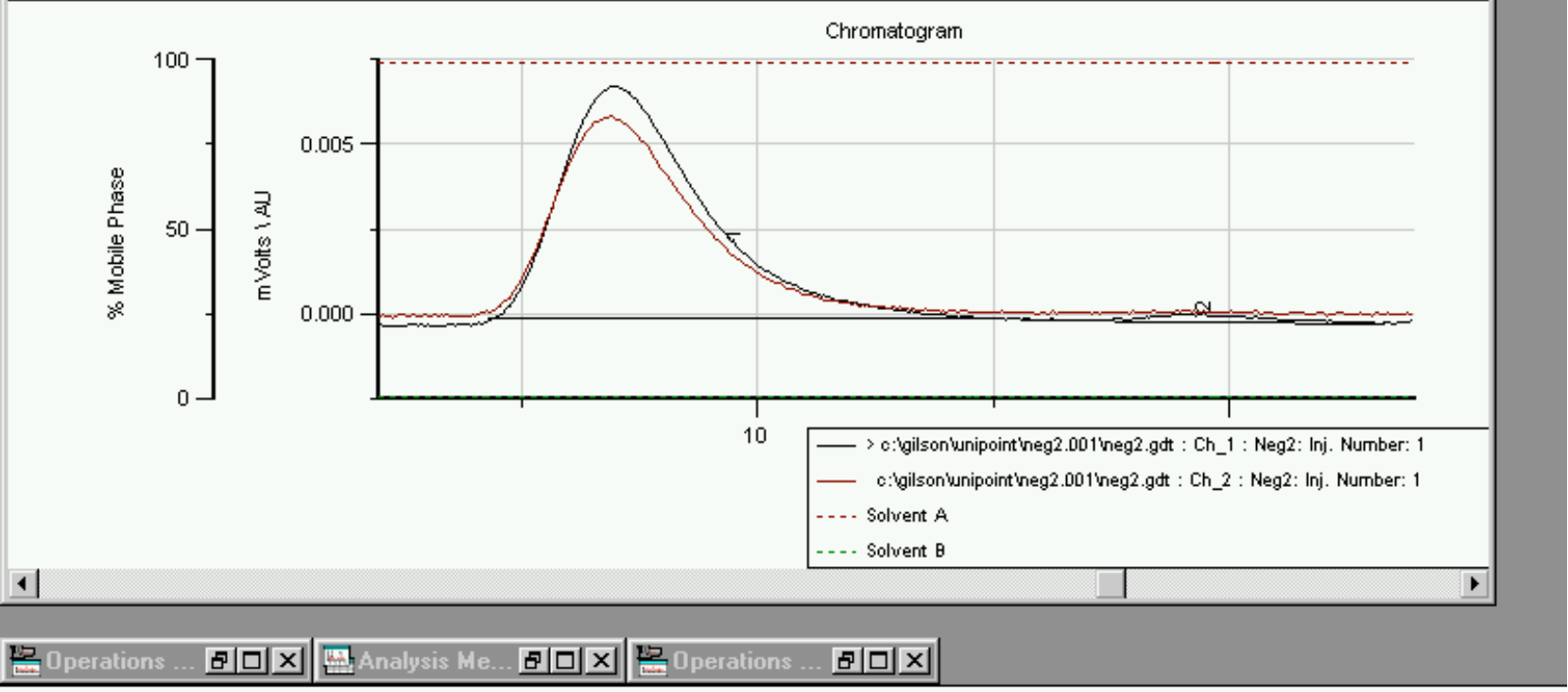




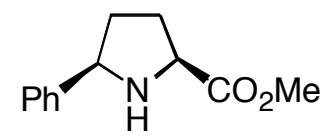

cis-22

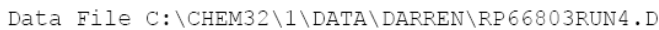
Sample Name: ds other $/ \mathrm{p} 4$ run 1
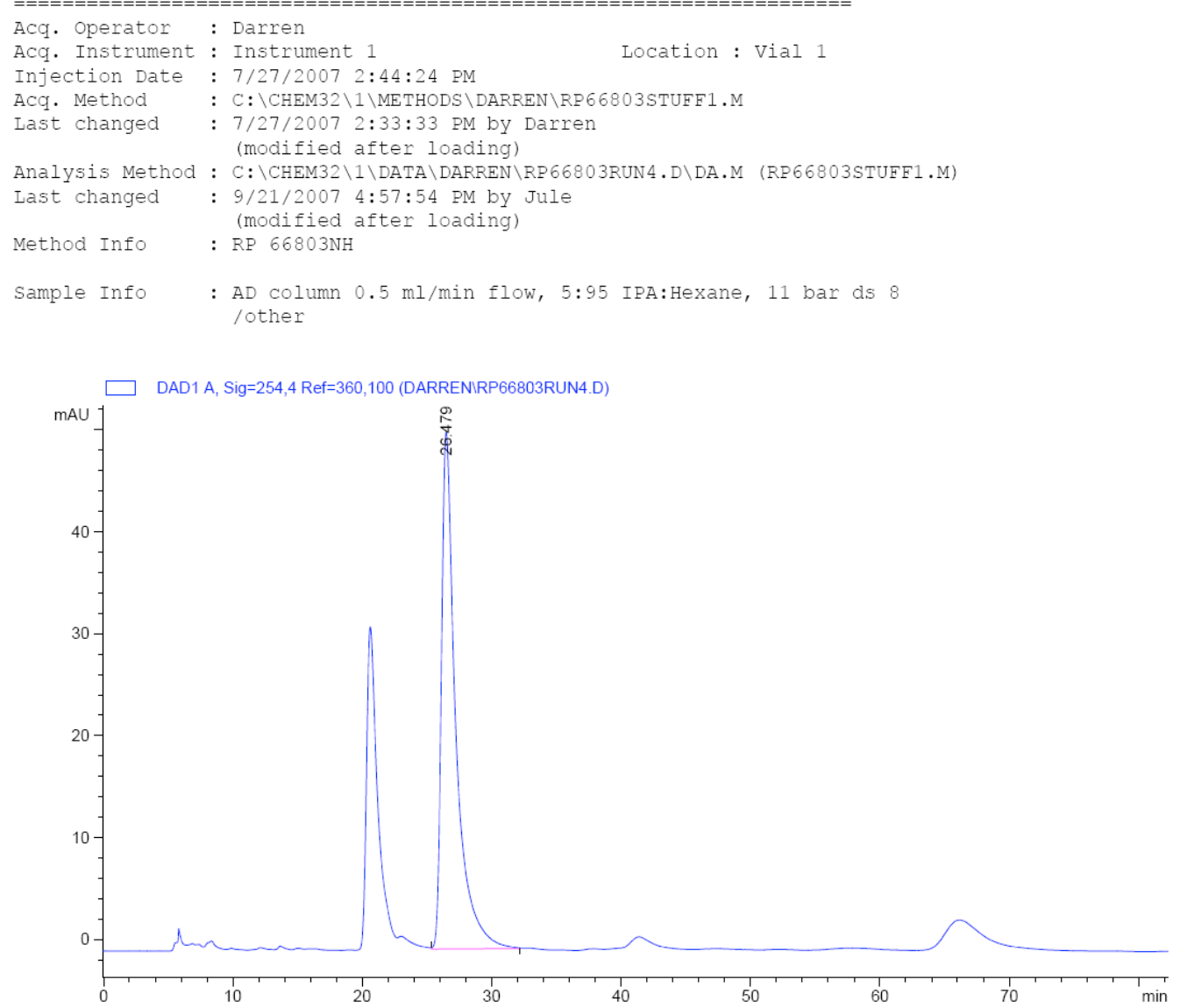

Area Percent Report

\begin{tabular}{|c|c|}
\hline sorted By & : \\
\hline Multiplier & : \\
\hline Dilution & : \\
\hline
\end{tabular}

Use Multiplier \& Dilution Factor with ISTDs

Signal 1: DAD1 A, Sig=254,4 Ref $=360,100$

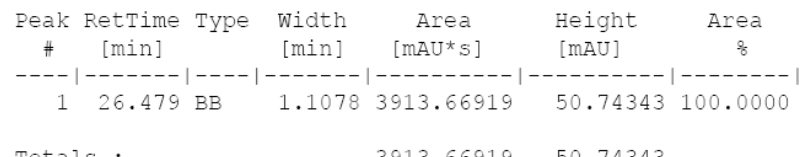

Totals : $\quad 3913.66919 \quad 50.74343$ 


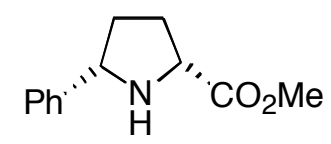

ent-cis-22

independently

synthesised

Data File C: $\backslash$ CHEM32 $31 \backslash$ DATA $\backslash$ DARREN $\backslash$ RP 66803 RUN3. D
Sample Name: ds $8.71 / \mathrm{p} 4$ run1

Acq. Operator : Darren

Acq. Instrument : Instrument 1

Injection Date : 7/27/2007 1:27:03 PM

Acq. Method : C: $\backslash$ CHEM32 $\backslash 1 \backslash$ METHODS $\backslash$ DARREN $\backslash R P 66803 S T U F F 1 . M$

Last changed

$: C: \backslash$ CHEM $32 \backslash 1 \backslash$ METHODS $\backslash$ DARREN $\backslash R P 66803 S T U F F 1 . M$
$: 7 / 27 / 2007 \quad 1: 25: 13$ PM by Darren

(modified after loading)

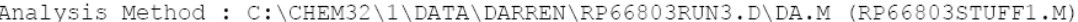

Last changed : 9/21/2007 4:59:48 PM by Jule

Method Info

(modified after loading)

Sample Info : AD column $0.5 \mathrm{ml} / \mathrm{min}$ flow, 5:95 IPA:Hexane, 11 bar ds 8 $/ 71 / \mathrm{p} 4$

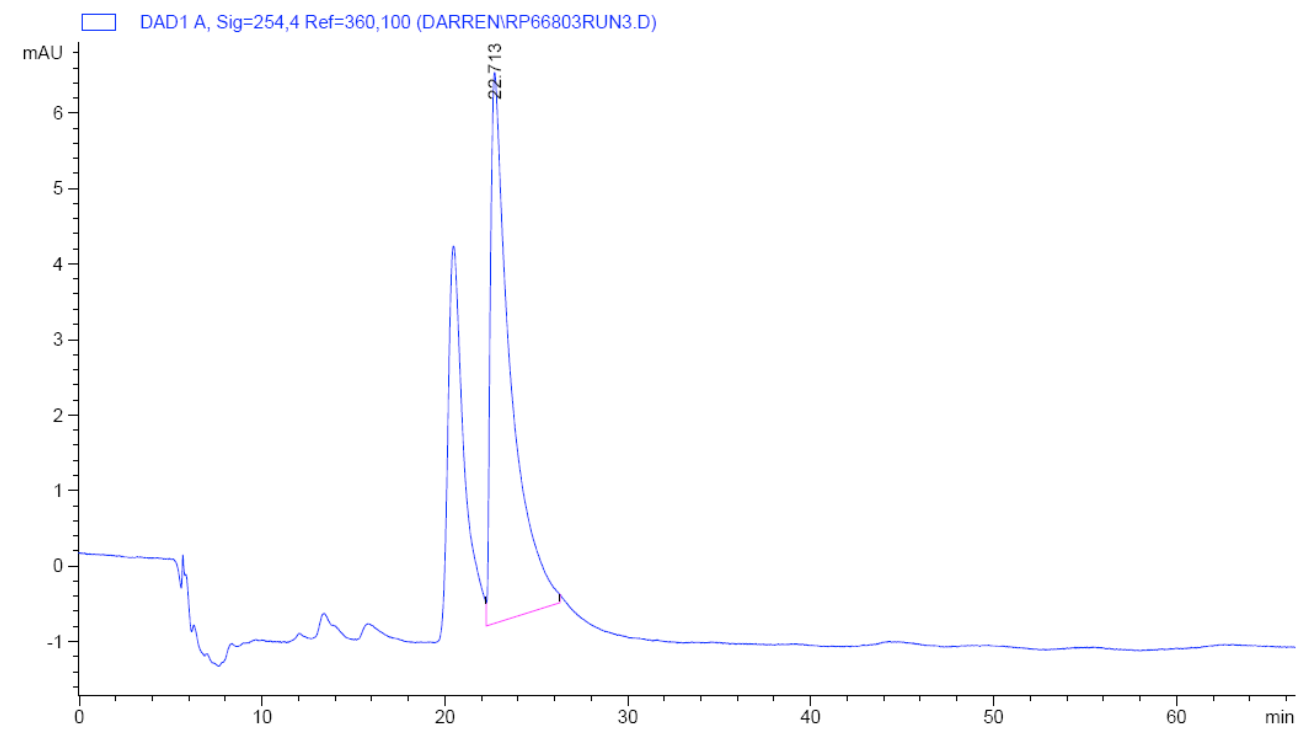

Area Percent Report

\begin{tabular}{|c|c|c|c|c|}
\hline sorted By & : & Signal & & \\
\hline Multiplier & : & 1.0000 & & \\
\hline Dilution & : & 1.0000 & & \\
\hline \multicolumn{5}{|c|}{ Use Multiplier \& Dilution Factor with ISTDs } \\
\hline \multicolumn{5}{|c|}{ Signal 1: DAD1 A, Sig $=254,4$ Ref $=360,100$} \\
\hline $\begin{array}{l}\text { Peak RetTime Type } \\
\# \quad[\text { min] }\end{array}$ & $\begin{array}{l}\text { Width } \\
\text { [min] }\end{array}$ & $\begin{array}{c}\text { Area } \\
{\left[\mathrm{MAU}^{*} \mathrm{~S}\right]}\end{array}$ & $\begin{array}{l}\text { Height } \\
\text { [mAU] }\end{array}$ & $\begin{array}{c}\text { Area } \\
\frac{8}{6}\end{array}$ \\
\hline$----|------|----\mid$ & ------1 & --------1 & ------- & $|-------|$ \\
\hline $122.713 \mathrm{VB}$ & 1.0403 & 560.62384 & 7.29767 & 100.0000 \\
\hline Totals : & & 560.62384 & 7.29767 & \\
\hline
\end{tabular}




\section{References for supporting information:}

(1) Larrow, J. F.; Jacobsen, E. N. Org. Synth. 1997, 75, 1.

8939.

(2) Kizirian, J.-C.; Cabello, N.; Pinchard, L.; Caille, J.-C.; Alexakis, A. Tetrahedron 2005, 61,

(3) Cabello, N.; Kizirian, J.-C.; Gille, S.; Alexakis, A.; Bernardinelli, G.; Pinchard, L.; Caille, J.C. J. Org. Chem. 2005, 70, 4835.

(4) Hoffmann, R. W.; Klute, W.; Dress, R. K.; Wenzel, A. J. Chem. Soc., Perkin Trans. 2 1995, 1721.

(5) Kerrick, S. T.; Beak, P. J. Am. Chem. Soc. 1991, 113, 9708.

(6) McGrath, M. J.; O’Brien, P. Synthesis 2006, 2233.

(7) Hodgson, D. M.; Lee, G. P.; Marritot, R. E.; Thompson, A. J.; Wisedale, R.; Witherington, J. J. Chem. Soc., Perkins Trans 1 1998, 2151.

(8) Crepy, K. V. L.; Imamoto, T. Org. Synth. 2005, 52, 22.

(9) Muci, A. R.; Campos, K. R.; Evans, D. A. J. Am. Chem. Soc. 1995, 117, 9075.

(10) McGrath, M. J.; O’Brien, P. J. Am. Chem. Soc. 2005, 127, 16378.

(11) Park, S. H.; Kang, H. J.; S., K.; Park, S.; Chang, S. Tetrahedron: Asymmetry 2001, 12, 2621.

(12) Coldham, I.; Fernàndez, J. C.; Snowden, D. J. Tetrahedron Lett. 1999, 40, 1819.

(13) Takahata, H.; Kubota, M.; Momose, T. Tetrahedron: Asymmetry 1997, 8, 2801.

(14) Peroche, S.; Remuson, R.; Gelas-Mialhe, Y.; Gramain, J.-C.; Tetrahedron Lett. 2001, 4617. Tetrahedron Lett. 2001, 42, 4617.

(15) Fleurant, A.; Cèlèrier, J. P.; Lhommet, G. Tetrahedron: Asymmetry 1992, 3, 695.

(16) Campos, K. R.; Klapars, A.; Waldman, J. H.; Dormer, P. G.; Chen, C. Y. J. Am. Chem. Soc. 2006, 128, 3538 .

(17) Haddad, M.; Imoga_, H.; Larchevêque, M. J. Org. Chem. 1998, 63, 5680.

(18) Davis, F. A.; Fang, T.; Goswami, R. Org. Lett. 2002, 4, 1599.

(19) Severino, E. A.; Costenaro, E. R.; Garcia, A. L. L.; Correia, C. R. D. Org. Lett. 2003, 5, 305. 